\title{
Dysfunctional signaling underlying endometriosis: current state of knowledge
}

\author{
1Department of Obstetrics and Gynecology, Dong-A University, College of Medicine, Busan, Republic of Korea \\ 2Department of Molecular and Cellular Biology, Baylor College of Medicine, Houston, Texas, USA \\ ${ }^{3}$ Center for Reproductive Medicine, Baylor College of Medicine, Houston, Texas, USA \\ ${ }^{4}$ Dan L Duncan Comprehensive Cancer Center, Baylor College of Medicine, Houston, Texas, USA \\ ${ }^{5}$ Center for Drug Discovery, Baylor College of Medicine, Houston, Texas, USA
}

Yeon Jean Cho',2, Seung Hyun Lee', Jung Woo Park', Myoungseok Han', Mi Jin Park² and Sang Jun Han²,3,4,5

Correspondence should be addressed to S J Han: sjhan@bcm.edu

\begin{abstract}
Endometriosis is defined as the presence of endometrial tissue outside the uterine cavity. It affects approximately $5-10 \%$ of women of reproductive age. Endometriosis is associated with dysmenorrhea, dyspareunia and, often, severe pelvic pain. In addition to pain, women with endometriosis often experience infertility. Defining the molecular etiology of endometriosis is a significant challenge for improving the quality of women's lives. Unfortunately, the pathophysiology of endometriosis is not well understood. Here, we summarize the potential causative factors of endometriosis in the following three categories: (1) dysregulation of immune cells in the peritoneal fluid and endometriotic lesions; (2) alteration of apoptotic signaling in retrograde menstrual tissue and cytotoxic T cells involved in endometriosis progression and (3) dysregulation of oxidative stress. Determining the molecular etiology of these dysregulated cellular signaling pathways should provide crucial clues for understanding initiation and progression of endometriosis. Moreover, improved understanding should suggest new molecular therapeutic targets that could improve the specificity of endometriosis treatments and reduce the side effects associated with current approaches.
\end{abstract}

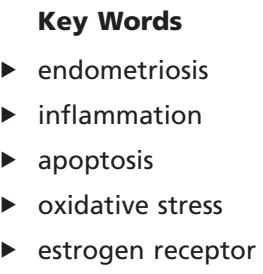

Journal of Molecular Endocrinology (2018) 60, R97-R113

\section{Introduction}

Endometriosis, defined as the presence of endometrial tissue outside the uterine cavity, results in severe pelvic pain and infertility in up to $5-10 \%$ of women of reproductive age (Eskenazi \& Warner 1997, Giudice 2010). Understanding the molecular etiology of endometriosis is essential to providing better treatment for this disease. There are many unresolved side effects of treatment, including adverse consequences for normal reproductive function, because current systemic estrogen deficiency therapy using gonadotropin-releasing hormone agonists (Descamps \& Lansac 1998), oral contraceptives, synthetic progestins and/or aromatase inhibitors prevents pregnancy (Attar \& Bulun 2006). To minimize these side effects, new and essential pathological pathways involved in endometriosis and endometriosis-associated dysfunction need to be evaluated.

There are several hypotheses regarding how endometriosis is initiated and progresses (Bulun 2009). The most widely accepted hypothesis involves retrograde menstruation (Sampson's hypothesis), wherein viable endometrial tissue fragments move into the pelvic cavity through the fallopian tubes during menstruation (Sampson 1927). These refluxed endometrial cells subsequently adhere to various tissues (such as the ovary, peritoneum, 
intestine and uterus), invade them and then proliferate until they become endometriotic lesions. Abnormalities of the genital tract, genetic predispositions, hormonal imbalances, altered immune surveillance, inflammatory responses and abnormal regulation of endometrial cells are potential causative drivers of endometriosis progression (Sourial et al. 2014). Although numerous studies have sought to determine the causative factors underlying the initiation and progression of endometriosis, the precise pathogenesis of endometriosis remains unknown. To help address this crucial question, we have summarized how the dysregulation of inflammation, apoptosis and oxidative stress signaling in immune cells, endometriotic lesions and peritoneal fluid drives the initiation and progression of endometriosis (Gupta et al. 2006, Barrier 2010, Taniguchi et al. 2011). A review of the literature was conducted to identify the most relevant studies reported in the English language. We searched the PubMed MEDLINE electronic database (https://www.ncbi.nlm. nih.gov/pubmed) for articles published between 1996 and 2017. The major keywords used were as follows: 'endometriosis and inflammation', 'endometriosis and immune dysregulation', 'endometriosis and apoptosis' and 'endometriosis and oxidative stress'. Here, our goal was to present relevant research related to the pathophysiology of endometriosis, and we considered both in vitro studies using human samples and animal model studies. To specify our purpose, we have included additional keywords as follows: 'T-cell/B-cell dysfunction', 'macrophage', 'natural killer cells', 'cytokine signal' and 'inflammation and estrogen receptor' along with endometriosis. Moreover, references in each article were searched to identify studies potentially overlooked in our initial search.

\section{Dysregulation of immune signaling during endometriosis progression}

During each menstrual cycle, viable endometrial fragments are transported into the peritoneal area by retrograde menstruation. Several studies have indicated that endometriosis patients have dysregulated immune systems that allow retrograde menstrual tissue to survive. For example, endometriosis patients have elevated levels of activated macrophages, $\mathrm{T}$ and $\mathrm{B}$ cells, but reduced levels of cytotoxic natural killer (NK) cells compared to healthy women (Jeung et al. 2016). They also show significant upregulation of stem cell growth factor $b$ (SCGFB), interleukin (IL) 8, human growth factor (HGF) and monocyte chemoattractant protein 1 (MCP1) and downregulation of IL13 (Jorgensen et al. 2017). These dysregulated immune cells and their cytokine networks could stimulate the initiation and progression of endometriosis.

\section{Alterations of macrophages and their cytokine profiles in endometriosis}

Macrophages, the internal components of the mononuclear phagocyte system, are derived from bone marrow progenitors and enter the bloodstream as monocytes. In peripheral tissues, macrophages are matured and activated in response to various external stimuli (such as lineage-determining growth factors, $\mathrm{T}$ helper (Th) cell cytokines and microbial products) to modulate the immune system (Santanam et al. 2002).

\section{Are macrophages required for the progression of endometriosis?}

Significantly increased numbers of macrophages are detected in eutopic endometria in women with endometriosis (Berbic et al. 2009), raising questions regarding their role during endometriosis progression. A rat endometriosis model showed that macrophage depletion using liposomal alendronate (LA) effectively inhibited the initiation and growth of endometriotic lesions, as determined by reduced implantation rates, adhesion scoring, implant size and weight and numbers of infiltrating macrophages in implants following LA treatment compared to vehicle treatment (Haber et al. 2009). Another study revealed that endometrial fragments adhered to and implanted in the peritoneal wall, whereas endometriotic lesions failed to organize and develop in the absence of macrophages because blood vessels failed to reach the inner layers of endometriotic lesions, which subsequently stopped growing (Bacci et al. 2009). These observations suggest an important role for macrophages in endometriosis progression.

\section{How do macrophages drive endometriosis progression?}

As macrophages secrete various cytokines to modulate normal cell functions, dysregulated macrophage-secreted cytokines havebeen associated with several diseases (Arango Duque \& Descoteaux 2014). An abundance of peritoneal neutrophils and macrophages in the peritoneal fluid of endometriosis patients increases the levels of vascular endothelial growth factor (VEGF), which stimulates endometriosis progression (Lin et al. 2006). Higher 
levels of macrophages may play a role in endometriosis by increasing the levels of cytokines responsible for amplifying the angiogenic signal. Interleukin 24 (IL24) is a novel tumor suppressor gene active in a broad range of human cancer cells. In decidual stromal cells, IL24 also significantly restricts the stimulatory effects of estrogen (Shao et al. 2013). Interestingly, macrophages markedly reduce the expression of IL24 in endometrial stromal cells to limit the inhibitory effects of IL24 on cell viability and invasion, as well as on the expression levels of the proliferation-related gene Ki-67, proliferating cell nuclear antigen (PCNA) and cyclooxygenase 2 (COX2) (Shao et al. 2016). Macrophage-mediated downregulation of IL24 leads to the increased proliferation and invasiveness of endometrial stromal cells and contributes to endometriosis progression.

Tumor growth factor (TGF) $\beta$ levels are also elevated in endometriotic lesions and macrophages in women with endometriosis compared to healthy women (Omwandho et al. 2010). TGF $\beta$-mediated autocrine and paracrine signaling in peritoneal macrophages plays an essential role in endometriosis progression by stimulating macrophage DNA synthesis, macrophage cell-cell interactions and the expression of macrophage cell surface adhesion molecules, such as integrin- $\alpha / \beta$ (Dou et al. 1997).

\section{Is there any difference in the macrophage populations between the normal endometrium and endometriotic lesions?}

Macrophages are activated into classic (M1) or alternative (M2) phenotypes depending on the type of stimulation (Martinez \& Gordon 2014). Lipopolysaccharides (LPS), interferon- $\gamma$ (IFN- $\gamma$ ) and granulocyte-macrophage colonystimulating factor (GM-CSF) induce macrophages toward the M1 phenotype. M1 macrophages produce significant levels of pro-inflammatory cytokines, such as IL1 $\beta$, tumor necrosis factor (TNF), IL12, IL18 and IL23 (Wang et al. 2014a). These help drive antigen-specific Th1 and Th17 cell inflammatory responses that suppress tumor cell growth (Roberts et al. 2015). In addition to proinflammatory cytokines, M1 macrophages upregulate the expression of intracellular protein suppressor of cytokine signaling 3 (SOCS3) and activate inducible nitric oxide synthase (NOS2 or iNOS) to produce NO from L-arginine and inhibit tumor growth (Arnold et al. 2014). Macrophages are guided toward the M2 type by fungal cells, immune complexes, helminth infections, complement components, apoptotic cells, macrophage colony-stimulating factor (MCSF), IL4, IL13, IL10 and transforming growth factor (TGF) $-\beta$ (Martinez \& Gordon 2014). Activated M2 macrophages secrete high levels of IL10, IL1, IL1ra and IL6 to stimulate tumor growth (Arango Duque \& Descoteaux 2014).

A rhesus macaque model of endometriosis revealed that, compared to controls, the activation state of macrophages in endometriosis tissues in nonhuman primates was skewed toward the M2 phenotype (Smith et al. 2012). Large peritoneal macrophages (LPMs) and small peritoneal macrophages (SPMs) have been found to polarize toward either M1 or M2 cells, respectively, in a murine model. Accordingly, the proportion of SPMs increased immediately after peritoneal injection of endometrial tissue, whereas LPMs exhibited the opposite trend (Yuan et al. 2017). Thus, it is possible that retrograde menstrual tissues could stimulate peritoneal macrophage polarization to the M2 type. In human endometriosis patients, there is high M2 macrophage polarization, and in vitro co-culture analyses have shown that M2 macrophages significantly upregulate proliferation of endometrial stromal cells by activating signal transducer and activator of transcription 3 (STAT3) signaling (Itoh et al. 2013). STAT3 signaling is aberrantly activated in epithelial and endometrial stromal cells in human endometriotic lesions (Kim et al. 2015). Therefore, endometriosis-associated M2 macrophages may stimulate STAT3 signaling in endometriotic lesions and thereby stimulate endometriosis.

\section{What causative factors drive M2 macrophage polarization in endometriotic cells?}

M2 macrophage polarization is regulated by the endometrium. Abnormal expression of indoleamine 2,3-dioxygenase-1 (IDO1) in endometrial stromal cells promotes an inflammatory response that subsequently initiates M2 macrophage polarization, which may facilitate the survival of retrograde menstrual tissues (Mei et al. 2017). Fractalkine (FKN), which is secreted by eutopic endometrial stroma cells, also stimulates M2 macrophage polarization and enhances endometriosis progression (Wang et al. 2014b). FKN induces M2 macrophage polarization by decreasing CD86 expression. In addition, FKN increases the expression of matrix metalloproteinase 9 (MMP9) by decreasing the expression of tissue inhibitor of MMP1 and 2. This promotes the invasiveness of endometrial stromal cells by activating p38 mitogenactivated protein kinases (MAPKs) and the integrin $\beta 1$ signaling pathway to stimulate endometriosis progression (Collette et al. 2006, Wang et al. 2014b). 
Exposure to endocrine-disrupting chemicals interferes with the endocrine system, causing cancerous tumors, birth defects and other developmental disorders, resulting in the progression of several human diseases (Mallozzi et al. 2017, Ribeiro et al. 2017). For example, exposure to 2,3,7,8-tetrachlorodibenzo-p-dioxin (TCDD) compounds stimulate endometriosis progression (Smarr et al. 2016). To induce endometriosis, TCDD alters patterns of macrophage activation. Combining $17 \beta$-estradiol with TCDD has a synergistic effect on the induction of M2 macrophage activation when macrophages are co-cultured with endometrial stromal cells, because it activates STAT3 and p38 MAPK signaling pathways (Wang et al. 2015). In addition to in vitro assays, the combination of TCDD and high levels of local $17 \beta$-estradiol in endometriotic lesions has been shown to synergistically induce M2 macrophage polarization and stimulate endometriosis in humans (Delvoux et al. 2009).

Annexin A2 is involved in various cellular processes, such as cell motility, cytoskeletal regulation and endocytosis. Levels of annexin A2 are markedly reduced in peritoneal macrophages from women with endometriosis compared to controls, and downregulation of annexin A2 inhibits the phagocytic capacity of macrophages (Wu et al. 2013). The level of annexin A2 mRNA in macrophages is reduced by prostaglandin E2 (PGE2) via the EP2/EP4 receptor-dependent signaling pathway. Indeed, elevated levels of PGE2 have been detected in endometriotic lesions (Rakhila et al. 2015), where they may reduce the ratio of M1/M2 peritoneal macrophages and stimulate the progression of endometriosis.

Endometriotic lesions exhibit high levels of the $\mathrm{C}-\mathrm{C}$ chemokine regulated on activation, normal T-cell expressed and secreted (RANTES). During osteogenesis, RANTES stimulates the transition of M1 to M2 macrophages in osteoprogenitors (Cordova et al. 2017). Elevated RANTES levels has been linked to endometriosis progression (Hornung et al. 2001, Wang et al. 2010) and is likely involved in M2 peritoneal macrophage polarization in endometriosis patients. TCDD promotes RANTES expression, and a combination of $17 \beta$-estradiol and TCDD significantly enhanced RANTES secretion in an endometriosis-associated human endometrial cell co-culture system, recruiting greater numbers of macrophages (Wang et al. 2010). RANTES could be a molecular therapeutic target for endometriosis, as suggested by the action of shikonin, an anti-inflammatory phytocompound derived from Lithospermum erythrorhizon, that mediates the inhibition of RANTES secretion and reduces endometriosis progression (Yuan et al. 2014).
The activation of TGF $\beta$ signaling in endometriosis also induces M2 macrophage polarization to stimulate inflammatory signaling and tissue repair (Gong et al. 2012).

\section{Dysregulation of T-cell-mediated cytokine profiling in endometriosis}

Lymphocyte subpopulations in endometriotic lesions are markedly different from those in normal endometrial tissue. Specifically, endometriotic lesions display increased numbers of CD4 and CD8 cells and activated T cells compared to normal endometrial tissue (Witz et al. 1994). Additionally, T-cell subtypes are also differentially regulated. The proportion of Th1 lymphocytes is significantly lower, whereas the Th17 lymphocyte fraction is significantly elevated in endometriotic lesions (Takamura et al. 2015). One recent study has shown that IL-10+Th17 cell population is significantly elevated in the peritoneal fluid of endometriosis patients as compared to the women without endometriosis (Chang et al. 2017). Interestingly, elevation of IL-10+Th17 cell population is associated with increased levels of IL-27, IL-6 and TGF- $\beta$. Especially, TGF- $\beta$ stimulates IL-10 production in Th17 cells in vitro and in vivo in human endometrial stromal cells to stimulate the proliferation and implantation of ectopic lesions and accelerate the progression of endometriosis (Chang et al. 2017). Although these patterns are not fully understood, this differential T lymphocyte activation appears to clearly be involved in the pathophysiology of endometriosis.

\section{Altered ratios of Th1/Th2 cells in endometriotic lesions}

CD4+ $\mathrm{T}$ lymphocytes, or Th cells, can be further subdivided into Th1 and Th2 cells, and the cytokines they produce are referred to as Th1-type and Th2-type, respectively (Berger 2000). Th1-type cytokines tend to generate pro-inflammatory responses, whereas Th2-type cytokines, such as IL4, IL5, IL10 and IL13, tend to elicit anti-inflammatory responses. A well-balanced Th1 and Th2 response is important for various immune challenges (Berger 2000). In endometriotic lesions, the levels of IFN$\gamma$, IL10 and the ratios of IL4/IFN- $\gamma$, IL4/IL2 IL10/IFN- $\gamma$, and IL10/IL2 are significantly elevated in the peritoneal fluid of endometriosis patients compared to healthy controls (Podgaec et al. 2007), which reflects a shift toward the Th2 immune response. Endometriosis progression may be associated with a reduced $\mathrm{Th} 1 / \mathrm{Th} 2$ ratio among $\mathrm{T}$ cells in the peritoneal fluid. 


\section{Role and determinants of Th2 cytokine} production during endometriosis progression

In humans, cytokines secreted from Th2 cells stimulate endometriosis progression. For example, IL4, a typical Th2 cytokine, has been shown to increase the mRNA expression

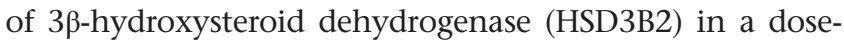
dependent manner (Urata et al. 2013). HSD3B2 is a pivotal enzyme for estrogen production. IL4 increases local estrogen levels to stimulate endometriosis progression. In addition, IL4 increases the proliferation of endometriotic stromal cells by activating p38 MAPK, stress-activated protein kinase/cJun kinase and p42/44 MAPK to stimulate endometriosis progression (OuYang et al. 2008b). Similar changes have been observed in mouse models. The weights and areas of endometriotic lesions have been found to be significantly reduced following treatment with INF- $\gamma$ and IL2 (Th1 cytokines) compared to treatment with IL4 and IL10 (Th2 cytokines) or saline solution (controls) (Mier-Cabrera et al. 2013). Th1 cytokine milieus suppress the progression of endometriosis in a murine endometriosis model.

Eutopic endometrial tissues from patients with endometriosis have higher mRNA levels of GATA-binding protein 3 (GATA3) compared to normal endometrial tissue (Chen et al. 2012). Expression of GATA3 is regulated by estrogen, and their synergistic action regulates Th2 cytokine (e.g., IL6, IL8 and IL10) expression in eutopic endometrial cells (Chen et al. 2016). Therefore, GATA3 integrates estrogen signaling to induce Th2 cytokine expression in endometriotic lesions, thereby promoting endometriosis progression.

IL6 levels are also elevated in endometrial stromal cells isolated from women with endometriosis compared to healthy controls (Tsudo et al. 2000). IL6 expression in endometriotic cells is induced by IL1 $\beta$ and TNF- $\alpha$ (Akoum et al. 1996). IL6 promotes CD4+ Th2 differentiation and inhibits Th1 differentiation via two independent molecular mechanisms (Diehl et al. 2000). Elevated IL6 levels promote Th2 differentiation by activating transcription mediated by nuclear factor of activated T cells (NFAT) (Diehl \& Rincon 2002). Additionally, IL6 inhibits Th1 differentiation by interfering with IFN- $\gamma$ signaling and the expression of suppressor of cytokine signaling 1 (SOCS1). These findings may support a role for IL6 in Th2 differentiation and Th2 cytokine production in endometriotic lesions.

\section{Alteration of Treg cells in endometriosis}

In addition to Th1 and Th2 cells, naïve $\mathrm{T}$ cells can differentiate into regulatory $\mathrm{T}$ (Treg) cells (Josefowicz et al.
2012). Treg cells suppress a range of immune responses, such as T-cell proliferation and activation (Giatromanolaki et al. 2008), as well as macrophage, B-cell, dendritic cell and NK-cell function (Thornton 2005). Because of its immunosuppressive function, the infiltration of large numbers of Treg cells into tumor tissues is associated with a poor prognosis (Enokida \& Nishikawa 2017). Consistent with tumor progression, a higher concentration of Treg cell phenotypes and/or expression markers has been detected in peritoneal fluid and endometriotic lesions but not in samples from healthy control women (Bellelis et al. 2013, Slabe et al. 2013, de Barros et al. 2017). To initiate and establish endometriosis, retrograde menstrual tissues in the peritoneal region must escape the host immune surveillance system. To achieve this, the large numbers of Treg cells in the T-cell population and endometriotic lesions decrease the recruitment of immune cells to prevent the recognition and targeting of retrograde menstrual tissues, thus allowing their survival and implantation into ectopic sites.

\section{Th17 cells and IL23 levels in endometriosis}

In addition to Th2 cytokines, the levels of IL23 and the Th17 cytokine IL17 are highly elevated in the peritoneal fluid of women with minimal or mild endometriosis (Andreoli et al. 2011). Th17 cells are involved in the pathogenesis of several autoimmune diseases, and endometriosis is associated with a higher risk (20-60\%) of autoimmune disease, such as multiple sclerosis, systemic lupus erythematosus and Sjögren syndrome (Ouyang et al. 2008a, Nielsen et al. 2011). In vitro stimulation of endometrial epithelial carcinoma cells, Ishikawa cells and HUVECs with IL17A revealed that IL17A treatment significantly increased angiogenic (VEGF and IL8), proinflammatory (IL6 and IL1 $\beta$ ) and chemotactic cytokine levels (G-CSF, CXCL12, CXCL1 and CX3CL1) (Ahn et al. 2015). The levels of IL23 were significantly higher in the peritoneal fluid of women with endometriosis compared to normal controls (Andreoli et al. 2011). Activated naïve T cells produce IL23, which then increases the levels of IL10 and IL17, both of which are required for endometriosis progression (Vanden Eijnden et al. 2005). Dysregulation of IL23 is also involved in several endometriosis-associated endometrial dysfunctions, such as infertility (Andreoli et al. 2011, Frazer et al. 2013).

\section{Altered T-cell activation and autoimmune properties of endometriosis}

Endometriosis is notitself an autoimmune disease; however, women with endometriosis may have been reported to 
have a higher risk of developing several autoimmune diseases, such as systemic lupus erythematosus, Sjögren's syndrome, multiple sclerosis and rheumatoid arthritis (Haga et al. 2005, Harris et al. 2016). This is somewhat controversial, however, as another study reported no correlation between them (Nielsen et al. 2011). In many autoimmune diseases, altered activation of $\mathrm{CD}^{+} \mathrm{T}$ cells plays a critical role in activating B cells to stimulate the production of autoantibodies (Palmer \& Weaver 2010). Consistent with autoimmune disease, the elevated levels of autoantibodies against the endometrium and ovary are highly elevated in endometriosis patient (Mathur et al. 1982). Therefore, altered activation of $\mathrm{CD}^{+} \mathrm{T}$ cells, as described earlier, might be involved in the elevation of autoimmune disease properties in endometriotic lesions.

\section{Dysfunction of NK cells in endometriosis patients}

NK cells secrete lytic granules containing granzyme, perforin and cytotoxins (such as IFN- $\gamma$ ) to destroy other cells (Topham \& Hewitt 2009). Cytotoxic NK cells therefore play a critical role in innate immunity to activate the host immune surveillance system following exposure to pathogens. Because of the crucial role of NK cells in innate immunity, dysregulation of NK cells causes immune-related disease progression (Smyth et al. 2005, Mandal \& Viswanathan 2015). The levels of molecular markers of cytotoxic NK cells, such as markers of activation (granzyme B, perforin, TRAIL, CD107a and CD69) and cell surface markers (NKp46, NKp44, NKG2D and CD16), are significantly reduced, but the proportion of immature NK cells (CD272CD11b2+) in the NK cell population (CD32CD56+) is elevated in the peritoneal fluid of endometriosis patients compared to normal women (Oosterlynck et al. 1991, Jeung et al. 2016).

\section{How are cytotoxic NK cells downregulated in endometriotic lesions compared to normal endometrial tissue?}

Cytokines with inhibitory effects on cytotoxic NK cells, such as inflammatory cytokines (IL6, IL8, IL1 $\beta$, IFN- $\gamma$ and TNF- $\alpha$ ) and non-inflammatory cytokines (CXCL3, CCL2, CCL5), are significantly elevated in the peritoneal fluid of endometriosis patients compared to controls (Malutan et al. 2015). Moreover, peritoneal fluid from endometriosis patients also shows elevated levels of antigens (HLA-G and HLA-E), immunoreceptor tyrosine-based inhibitory motif killer cell inhibitory receptors (ITIM-KIRs), inhibitory NK cell receptors containing Ig domains (KIR2DL1, KIR3DL1), EB6 and soluble intracellular adhesion molecule-1 (I-CAM), which also suppress cytotoxic NK cells (Jeung et al. 2016). In addition, HLA-G expression is detected in eutopic endometrial tissue of endometriosis patients during the menstrual phase (Thiruchelvam et al. 2015). Retrograde menstrual tissues show elevated levels of HLA-G in the peritoneal cavity, where they can interact with the immune surveillance system and counteract the cytotoxicity of NK cells. This would allow retrograde menstrual tissues to survive and implant, eventually developing into endometriotic lesions. Therefore, increased levels of inflammatory cytokines, antigens and inhibitory receptors in the peritoneal fluid and endometrium downregulate cytotoxic NK activity during the progression of endometriosis.

\section{Activation of B cells in endometriosis}

B cells underlie humoral immune responses by producing antibodies against antigens. Increased numbers of $\mathrm{B}$ cells are found in the blood and peritoneal fluids of endometriosis patients compared to healthy women (Osuga et al. 2011). Interestingly, transcriptional factors regulating B-cell function are differentially expressed in endometriosis patients compared with healthy women. For example, B lymphocyte inducer of maturation program (Blimp)-1, which is a crucial regulator of plasma cell differentiation, is significantly increased; the levels of B-cell leukemia lymphoma (Bcl)-6, its antagonist, are significantly reduced in the peritoneal cavities of endometriosis patients (Yeol et al. 2015). In addition to transcription factors, endometriotic lesions also have higher levels of cytokines that activate B cells, such as B lymphocyte stimulator (BLys) (Hever et al. 2007). BLys plays an important role in the normal development of $\mathrm{B}$ cells and their differentiation into plasma cells (Schiemann et al. 2001). Therefore, these factors can stimulate B-cell function in endometriosis patients.

These hyperactivated B lymphocytes appear to contribute to the pathogenesis of endometriosis by producing autoantibodies against the endometrium, DNA and phospholipids, as well as antinuclear antibodies (Osuga et al. 2011). A similar elevation of autoantibodies has also been observed in autoimmune diseases (Eggert et al. 2010). Because of the many similarities between endometriosis and autoimmune diseases, endometriosis may be treatable as an autoimmune disease (Nothnick 2001). 


\section{Alteration of cytokine profiling in endometriotic lesions}

In addition to immune cells, endometriotic lesions are themselves a source of secreted cytokines that stimulate endometriosis progression. For example, endometriotic epithelial cells have increased levels of TNF- $\alpha$ compared to normal endometrial tissue during endometriosis progression. Epithelial TNF- $\alpha$ activates the phosphoinositide 3-kinase (PI3K), MAPK, c-Jun N-terminal kinase (JNK), p38 and IкB kinase signaling pathways via autocrine responses to stimulate inflammation and invasion of endometriotic epithelial cells, thus favoring their proliferation (Grund et al. 2008). Endometriotic epithelial TNF- $\alpha$ also induces IL6 and IL8 expression in endometriotic stromal cells via nuclear factor-kappa-B $(\mathrm{NF}-\mathrm{kB})$ and activator protein (AP) 1 through paracrine responses to stimulate proliferation of endometriotic stromal cells (Sakamoto et al. 2003, Yamauchi et al. 2004). These dysregulated autocrine or paracrine cytokine signaling networks in endometriotic lesions are also involved in endometriosis progression.

In addition to $\mathrm{TNF} \alpha$, endometriotic lesions are a source of various cytokines, such as ENA78, RANTES, IL6 and IL8 (Akoum et al. 2001, Bertschi et al. 2013). IL6 plays a significant role in CD4+ T-cell differentiation (Dienz \& Rincon 2009), and IL8 induces T lymphocyte infiltration in target tissues (Taub et al. 1996). Therefore, IL6 and IL8 in endometriotic lesions might generate T-cell milieus specific for endometriotic lesions to enhance their survival.

\section{Inflammatory and estrogen receptor (ESR) signaling in endometriotic lesions and macrophages}

Peritoneal macrophages are activated by exposure to 17ß-estradiol (Hong \& Zhu 2004). Because a higher activity of the $17 \beta$-estradiol axis stimulates endometriosisassociated macrophage activation to synergistically induce endometriosis, endometriosis has been considered an estrogen-dependent inflammatory disease. In addition to higher local estradiol concentrations, ESR levels are also differentially regulated in endometriotic lesions in response to increased estradiol signaling. Accordingly, elevated levels of ESR2 but not ESR1 have been detected in endometriotic tissues compared to normal endometrial tissues. Elevated ESR2 stimulates prostaglandin production in endometriotic tissues through COX2 to promote endometriosis progression (Wu et al. 2010, Bulun et al. 2012). Increased prostaglandin levels suppress the immune system, allowing retrograde menstrual tissues to escape the immune surveillance system and develop into endometriotic lesions. In addition, ESR2 interacts with components of the cytoplasmic inflammasome to increase IL1 $\beta$ in endometriotic lesions, stimulating their adhesion and proliferation properties (Han et al. 2015). Therefore, increases in ESR2 function modulate the immune response to retrograde menstrual tissues, which can subsequently develop into endometriotic lesions. Hypomethylation of the ESR2 gene promoter region might contribute to higher ESR2 levels in endometriotic lesions (Xue et al. 2007), but detailed molecular mechanisms underlying ESR2 function in endometriosis progression remain unclear.

Peritoneal macrophages are activated upon $17 \beta$-estradiol treatment to stimulate endometriosis progression (Hong \& Zhu 2004), and expression levels of ESR2 are significantly increased in peritoneal macrophages of women with endometriosis (Montagna et al. 2008). Pretreatment of peritoneal macrophages with ERB-041, a selective ESR2 agonist, results in significant inhibition of LPS-induced iNOS expression by suppressing NF-kB activation and endometriosis progression (Harris et al. 2005, Xiu-li et al. 2009). Collectively, the alteration of the ESR2-estradiol axis in macrophages is another driver of endometriosis progression.

\section{Communication between immune cells and endometriotic lesions drives endometriosis progression}

We have discussed dysregulated immune signaling in both immune cells and endometriotic lesions. Interestingly, altered inflammatory signaling in immune cells induces endometriotic lesions to enhance endometriosis progression (Fig. 1). During the initiation of endometriosis, altered immune cells release pro-inflammatory cytokines (IL1, IL6, IL8, IL10, IL12, IL13, TNF- $\alpha$, VEGF and plateletderived growth factor (PDGF)) by activating the STAT, p38, extracellular signal-regulated kinase (ERK) and JNK signaling pathways. These cytokines bind to their receptors in endometriotic lesions and mediate further downstream signaling via NF-kB to initiate and establish endometriosis progression. For example, mRNA expression levels of steroidogenic acute regulatory protein (StAR), COX2, MMP9 and other pro-inflammatory cytokines is increased in endometriotic lesions as a result of NF-kB-mediated pro-inflammatory cytokines (Tsai et al. 2001). Elevated StAR expression is involved in estradiol production in endometriotic lesions, further promoting endometriosis progression. Moreover, increased local E2 levels directly induce COX2 expression to promote PGE2 production 


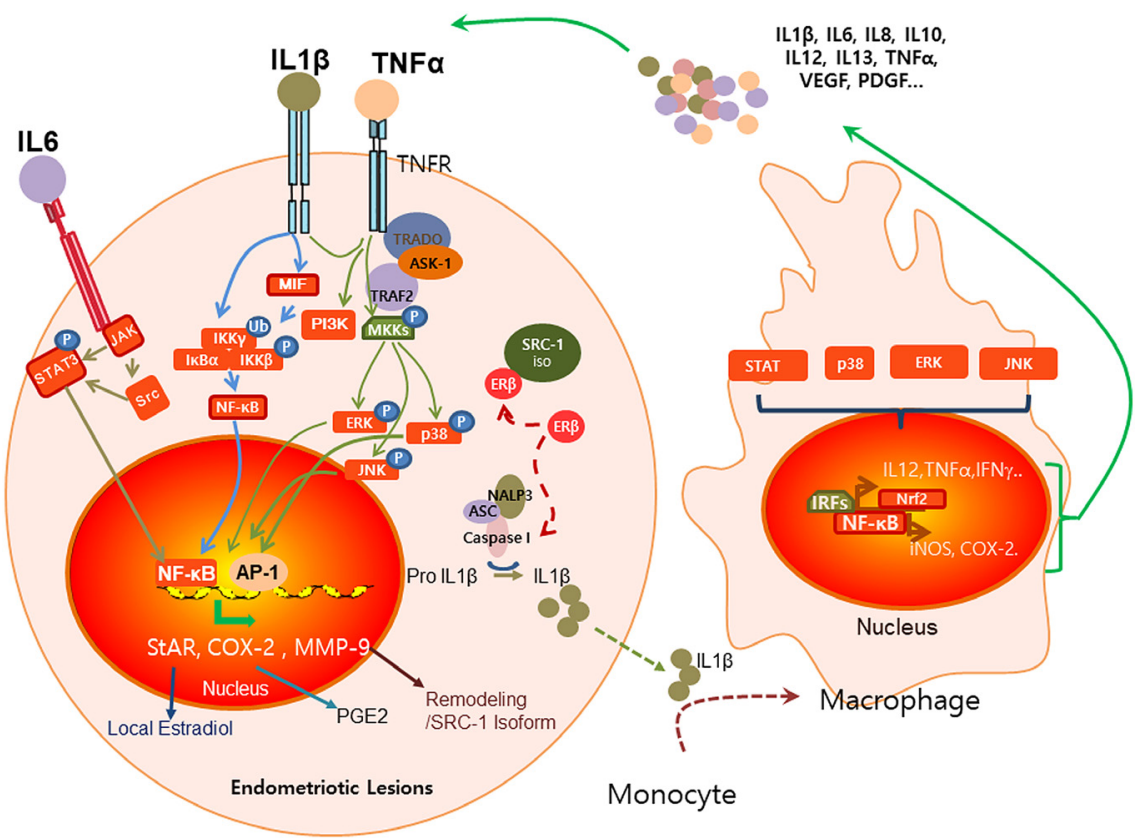

Figure 1

Cytokine signaling networks involving endometriotic lesions and peritoneal macrophages. Activated peritoneal macrophages express inducible nitric oxide synthase (iNOS) and COX2 through interferon regulatory factors (IRFs), NF-KB and nuclear factor (Nrf)2 through activation of STAT, p38, ERK and JNK signaling cascades. Activated macrophages then release cytokines (including IL1, IL6, IL8, IL10, IL12, IL13 and TNF $\alpha$ ), growth factors and angiogenic factors (VEGF and platelet-derived growth factor (PDGF)). The secreted TNF $\alpha$, IL $1 \beta$ and IL6 bind their membrane receptors in endometriotic lesions. The cytokine/cytokine receptor complex then activates PI3K, MKK, JNK, p38 and IKK pathways to induce the expression of inflammation and invasion mediators, such as StAR, COX2 and MMP9, through NF-KB and AP1 transcription factors to stimulate local estradiol formation, PEG2 formation and tissue remodeling and NCOA-1 isoform generation, which enhances the growth of endometriotic lesions. The estradiol/ESR2/NCOA-1 complex interacts with the cytoplasmic inflammasome to increase IL1 $\beta$ levels to induce monocyte differentiation into macrophages (Schenk et al. 2014). Therefore, cytokine crosstalk between endometriotic cells and macrophages is the main driver for the initiation, maintenance and progression of endometriosis.

and activate inflammasomes via ESR2 to induce IL1 $\beta$, thus enhancing the adhesion and proliferation of endometriotic lesions and endometriosis progression.

\section{Dysregulated apoptosis signaling in endometriotic lesions}

Impaired apoptosis in retrograde menstrual tissues and abnormal apoptosis in immune cells are associated with endometriosis progression (Taniguchi et al. 2011). Understanding the molecular mechanisms governing the dysregulation of apoptosis in endometriotic tissues and immune cells is crucial for determining the molecular etiology of endometriosis and providing new molecular therapeutic treatments. Here, we discuss how dysregulated apoptosis is involved in the progression of endometriosis.

\section{Reduced apoptosis in endometriotic lesions}

Compared to healthy women, apoptosis is significantly reduced in eutopic endometrial tissue in patients with endometriosis (Gebel et al. 1998). Specifically, endometriotic lesions show higher BCL2 (anti-apoptotic signaling) staining than normal endometrial tissue (Harada et al. 2004), as well as increased expression of c-myc (a cell-cycle regulator) and TGF- $\beta$; in contrast, reduced levels of the pro-apoptotic BCL2-associated X protein (BAX) are found (Meresman et al. 2000, Vetvicka et al. 2016, Yu et al. 2017). Collectively, the reduction of apoptosis in endometriotic lesions represents a concerted effort by retrograde menstrual tissues to evade immune surveillance and develop into endometriotic lesions.

\section{Dysregulation of intrinsic apoptosis signaling in endometriosis}

Apoptotic signaling occurs via two different pathways: intrinsic (or mitochondrial) and extrinsic (or death receptor-mediated) (Schleich \& Lavrik 2013). Suppression of the intrinsic apoptotic pathway has been detected in endometriotic lesions. The ratio of anti- to pro-apoptotic molecules, such as BCL2/BAX, is higher in mitochondria 
of eutopic endometrial tissues (Meresman et al. 2000) and in macrophages from endometriotic lesions. The BCL2 family of proteins constitutes a critical intracellular checkpoint of the intrinsic apoptotic pathway; increased BCL2 but decreased BAX expression levels are found in the proliferative phase of eutopic endometrial tissues from patients with endometriosis compared with normal endometrial tissue. Women with endometriosis have a large BCL2-positive macrophage population in the peritoneal fluid, whereas women without endometriosis have a peritoneal macrophage population that has elevated levels of BAX (McLaren et al. 1997). Interestingly, the expression profile of apoptosis-related proteins in endometriotic lesions is regulated in a location-dependent manner. For example, p53 and p21 are higher in ovarian endometriosis, whereas BCL2 expression is higher in peritoneal and colorectal endometriosis (Dufournet et al. 2006). A different mechanism of suppression of the intrinsic apoptotic pathway might be involved in the development of each type of endometriotic lesion, and targeting specific anti-apoptotic pathways may be useful as a component of endometriosis treatment for specific endometriotic lesions.

\section{Alteration of extrinsic apoptosis signaling in endometriosis}

\section{Fas/FasL}

The Fas/FasL axis is the traditional extrinsic apoptosis signaling cascade (Curtin \& Cotter 2003). Fas (DR2/CD95/ Apo-1) is a type I cell membrane protein (mFas), with an extracellular domain that binds FasL (CD95L/CD178/ Apo-1L) and a cytoplasmic domain that transduces the death signal (Peter et al. 2007, Strasser et al. 2009). Cell death signaling mediated by the Fas/FasL interaction plays an essential role in the immune system and in maintaining immune-privileged sites in the body. For example, Fas/FasL-mediated apoptosis kills cytotoxic T cells (Waring \& Mullbacher 1999). FasL is expressed in normal human endometrial cells, where it is stimulated by macrophage cytokines, such as PDGF and TGF- $\beta 1$ (GarciaVelasco et al. 1999). Higher levels of IL8 in the peritoneal fluid of endometriosis patients cause an increase in FasL expression in endometrial cells (Selam et al. 2002) and endometrial stromal cells. However, increased FasL does not induce apoptosis in endometrial stromal cells (Selam et al. 2006a). Ectopic epithelial cells of endometriotic lesions have simultaneously increased FasL expression and reduced Fas expression, irrespective of the menstrual cycle phase (Sbracia et al. 2016). Collectively, induction of FasL in endometrial cells may induce apoptosis in cytotoxic T cells expressing the Fas receptor, thus allowing them to evade immune surveillance and develop into endometriotic lesions.

\section{TNF $\alpha$-mediated apoptosis}

Changes in TNF- $\alpha$-mediated cell death signaling are also involved in endometriosis progression (Iwabe et al. 2000). During retrograde menstruation, the influx of retrograde menstrual tissues into the peritoneal cavity activates macrophages to secrete cytotoxic cytokines, such as TNF- $\alpha$, inducing apoptosis signaling in extrauterine endometrial fragments that need to be removed (Leavy 2015). In endometriosis patients, however, the molecular properties of retrograde menstrual tissues are altered in a way that allows escape from TNF- $\alpha$-mediated apoptosis. As endometriosis is an estrogen-dependent disease, nuclear receptor coactivator (NCOA)s may play an important role in endometriosis progression. Interestingly, endometriotic lesions have an elevated level of the NCOA-1 isoform, but not full-length NCOA-1 (Han et al. 2012). The NCOA-1 isoform is proteolytically generated from full-length NCOA-1 by MMP9 in endometriotic lesions. There, the NCOA-1 isoform, but not full-length NCOA-1, interacts with caspase 8 to prevent TNF- $\alpha$-mediated apoptosis by disrupting apoptosis complex II formation. Endometriotic lesions also express high levels of ESR2 (Hudelist et al. 2005), which then interacts with caspase 8 or components of the cell death machinery in endometriotic cells to block TNF- $\alpha$-induced apoptosis (Han et al. 2015). Specifically, high ESR2 induces the formation of apoptosis signal-regulating kinase 1(ASK1), serine/threonine kinase receptor-associated protein and the 14-3-3 protein complex to inhibit ASK1 activity required for TNF- $\alpha$-mediated apoptosis. Moreover, ESR2 disrupts apoptosome formation by interacting with and preventing the activation of caspase 9 in endometriotic lesions. Taken together, induction of the endometriosis-specific NCOA-1 isoform/ESR2 axis actively prevents TNF- $\alpha$-induced apoptosis signaling in endometriotic lesions by interacting with the apoptotic machinery (Fig. 2).

\section{Targeting the dysregulation of apoptosis signaling in endometriotic tissues}

In addition to endometriosis progression, the sophisticated regulation of apoptosis also plays an important role in embryonic development via the appropriate formation of various organs and structures (Haanen \& Vermes 1996). 


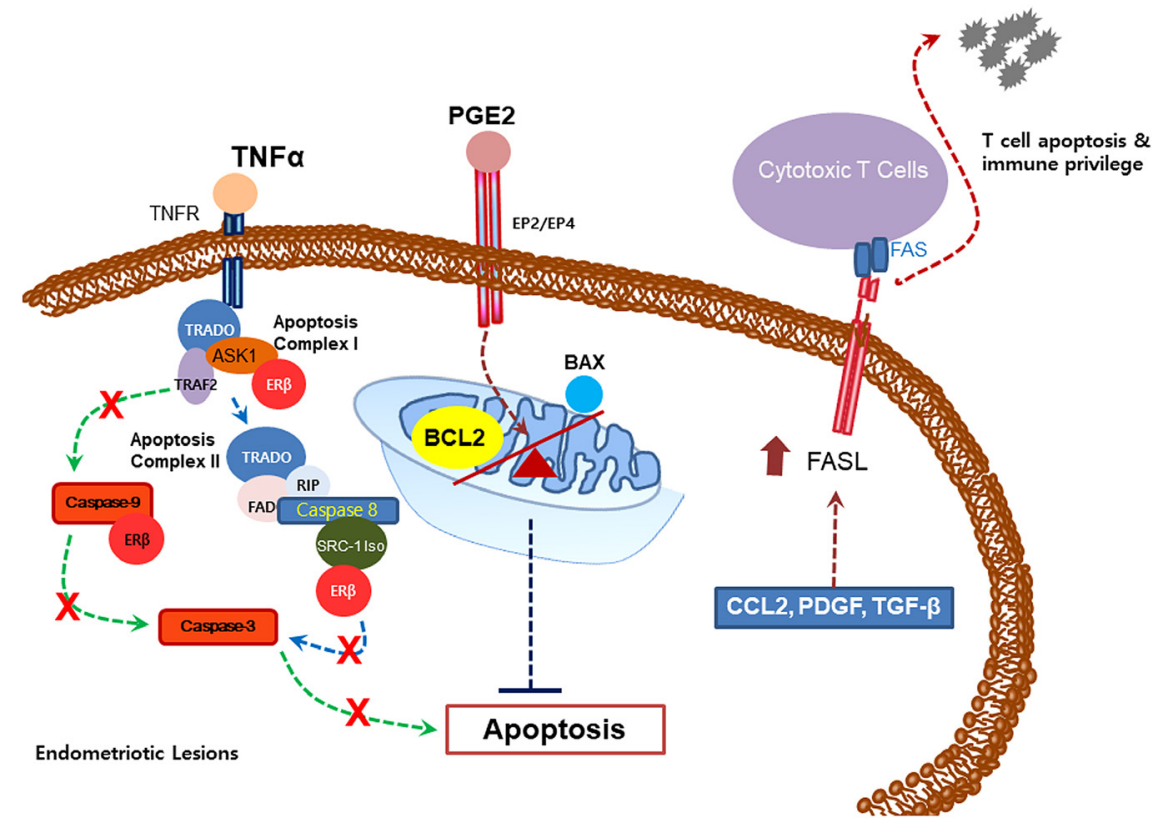

Figure 2

Dysregulation of apoptotic signaling in endometriosis. The decreased apoptosis of endometriotic cells and increased apoptosis of immune cells leads to immune privilege. TNF $\alpha$, elevated by retrograde menstruation, binds to tumor necrosis factor receptor (TNFR) to induce caspase 8-and caspase 9-mediated apoptosis in retrograde menstrual tissues. In endometriosis patients, however, elevated NCOA-1 isoform/ESR2 complex binds to ASK1 (apoptosis complex I), caspase 8 (apoptosis complex II) and caspase 9 (apoptosome) and suppresses extrinsic apoptosis signaling in retrograde menstrual tissues. The elevation of PGE2 in endometriosis patients increases the ratio of BCL2/BAX in mitochondria to inhibit intrinsic apoptosis signaling. The endometriotic lesions also exhibit elevated levels of FasL, which binds to Fas in cytotoxic T cells, causing cell death in cytotoxic T cells. This represents a critical defense mechanism of endometriotic lesions against destruction by cytotoxic $\mathrm{T}$ cells during retrograde menstruation.

Therefore, defective apoptosis signaling during embryogenesis may cause developmental abnormalities (Haanen \& Vermes 1996). Dysregulation of apoptosis is a key driver of many human diseases and may serve as an effective molecular therapeutic target for the treatment of many human diseases.

PGE2 levels are elevated in endometriosis patients; PGE2 promotes the survival of human endometriotic lesions through EP2 and EP4 receptors and activation of the ERK1/2, AKT, NF- $\mathrm{B}$ and $\beta$-catenin signaling pathways (Banu et al. 2009). Selective inhibitors of EP2 (AH6809) and EP4 (AH23848) suppress these cell survival pathways and enhance interactions between anti-apoptotic and pro-apoptotic proteins, thereby activating the intrinsic apoptotic pathways in human endometriotic cells.

Pro-inflammatory cytokines also regulate apoptotic signaling in various cells to modulate their cellular function (Grunnet et al. 2009). In endometriosis, dysregulated cytokines prevent apoptosis and promote the survival of endometriotic lesions. For example, secretion of CXCL8 is significantly higher in eutopic endometrial stromal cells of women with endometriosis compared to normal endometrial tissues, and elevated CXCL8 reduces apoptosis by upregulating BCL2 expression in these cells in an autocrine manner (Li et al. 2012). Anti-human CXCL8neutralizing antibodies suppress endometriosis progression by inducing apoptosis in endometriotic lesions. RANTES and IL8 attenuate apoptosis in endometriotic lesions (Selam et al. 2006b); shikonin-mediated inhibition of RANTES secretion reduces endometriosis progression (Yuan et al. 2014). Treatment with an IL8-neutralizing antibody also suppresses endometriosis progression by inhibiting the attachment of retrograde menstrual tissues and reactivating apoptosis in these cells (Arici 2002). Collectively, molecules that induce anti-apoptotic pathways in endometriotic lesions could be molecular therapeutic targets for alternative endometriosis treatments.

\section{Dysregulation of oxidative stress in endometriosis}

Healthy women exhibit balanced levels of reactive oxygen species (ROS) and antioxidants. An overabundance of ROS induces oxidative stress, impacting women throughout their reproductive lifespan, including in the initiation of endometriosis (Carvalho et al. 2012). Oxidative 
stress results in damage to cellular lipids, proteins and DNA, changing their molecular properties and possibly leading to disease. Importantly, ROS overproduction impairs cellular functions by inducing redox-sensitive transcription factor (such as NF-kB)-mediated expression of genes required for the initiation and progression of endometriosis (Fig. 3) (Defrere et al. 2011).

Erythrocytes, apoptotic endometrial tissue and cell debris transplanted into the peritoneal cavity by menstrual reflux, as well as macrophages, have all been cited as potential inducers of oxidative stress. Iron overload has been detected in the cells and peritoneal fluid of women with endometriosis compared to normal endometrial tissues (Van Langendonckt et al. 2002, Carvalho et al. 2012). Excessive iron induces deleterious ROS in the peritoneal environment, which enhances the attachment and growth of retrograde menstrual tissues (Alizadeh et al. 2015, Donnez et al. 2016). In a murine model, iron overload has been shown to further expand endometriosis by promoting epithelial cell proliferation at lesion sites (Defrère et al. 2006). Additionally, excessive iron levels may favor nitric oxide production, resulting in the impaired clearance of endometrial cells by macrophages (Pirdel \& Pirdel 2014). At present, it remains unclear why iron-mediated oxidative stress is maintained at high levels in endometriosis patients compared to healthy women. One possibility is that it is associated with alterations in ROS detoxification pathways and reductions in catalase levels, as observed in cancer patients (Ngo etal. 2009). Retrograde menstruation-mediated hyperactivated oxidative stress leads to stimulation of the ERK and PI3K/AKT/mTOR signaling pathways (Fig. 3), thus promoting adhesion, angiogenesis and proliferation of endometriotic lesions and subsequent endometriosis progression (McKinnon et al. 2016).

\section{Development of alternative endometriosis treatments based on drugs targeting the dysregulated immune system, apoptosis and oxidative stress}

The goal of endometriosis treatment is to relieve pain and/ or achieve successful pregnancies in infertile patients. Most current medical treatments induce systemic estrogen depletion, because estrogen signaling is an essential driver of endometriosis. However, many current clinical endometriosis treatments are not sufficiently effective and haveunacceptablesideeffects, becausethespecificmolecular etiology of endometriosis has not yet been elucidated. Here, we have discussed endometriosis-associated processes, including dysregulation of inflammation, antiapoptosis and oxidative stress in endometriosis patients. Therefore, these dysregulated cellular pathways provide

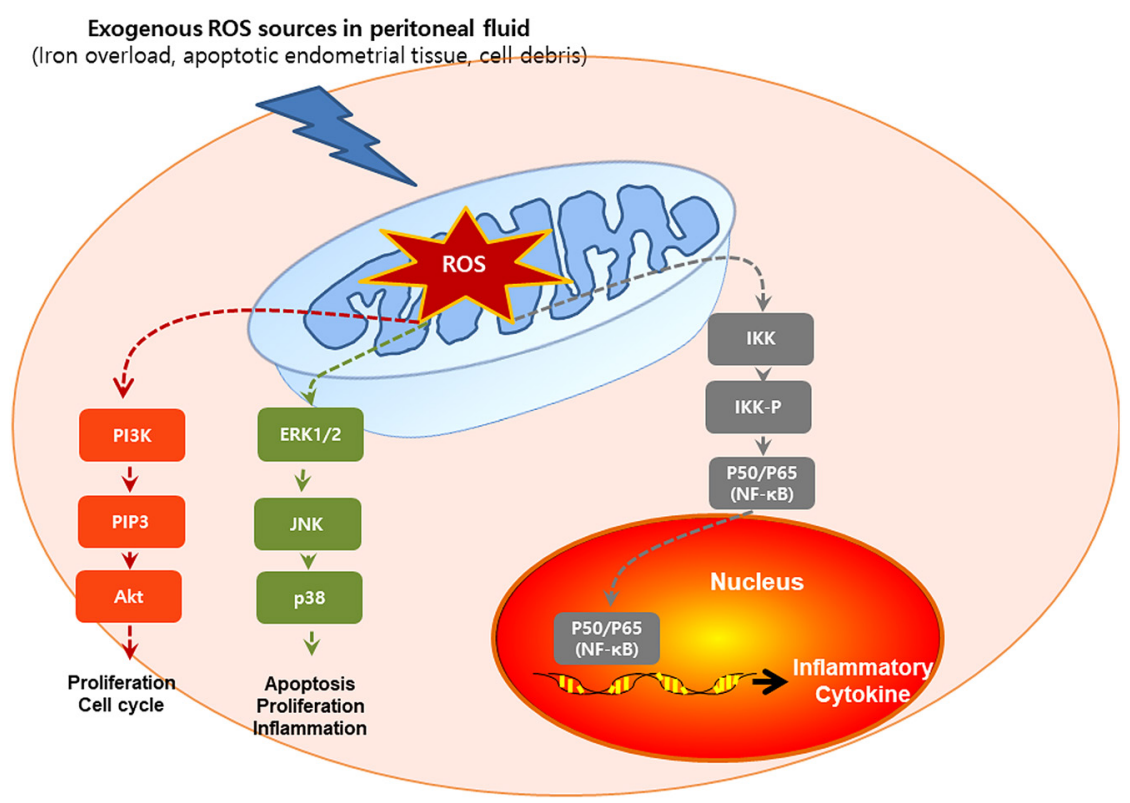

Figure 3

Alterations of oxidative stress pathways in endometriosis. An overload of erythrocytes, apoptotic endometrial tissue and cell debris in the peritoneal cavity stimulate the generation of ROS in mitochondria. The hyperactivated ROS stimulate ERK and PI3K/AKT/mTOR signaling pathways in endometriotic lesions to enhance adhesion, angiogenesis, and proliferation. Overproduction of ROS also impairs cellular function by altering gene expression profiles through the NF- $\mathrm{kB}$ signaling cascade to increase inflammatory cytokine production in endometriotic lesions, which enhances endometriosis progression. 
Table 1 Emerging medical therapies in endometriosis with human data: alternative hormonal agents as well as agents targeting endometriosis-specific inflammation, anti-apoptosis and oxidative stress.

\begin{tabular}{|c|c|c|c|c|}
\hline & Target site & Drug name & Results in human study & Main effect \\
\hline \multicolumn{5}{|l|}{ Hormonal agents } \\
\hline Aromatase inhibitor & $\begin{array}{l}\text { Block androstenedione to } \\
\text { estrone }\end{array}$ & Letrozole & Retrospecitve analysis (Abushahin et al. 2011) & $\begin{array}{l}\text { Reduce pain with } \\
\text { GnRh agonist }\end{array}$ \\
\hline GnRH antagonist & $\begin{array}{l}\text { Direct pituitary gonadotropin } \\
\text { suppression }\end{array}$ & Elagolix & RCT (Taylor et al. 2017) & Reduce pain \\
\hline SERMs & $\begin{array}{l}\text { Nonsteroid selective agonist or } \\
\text { antagonist effects in different } \\
\text { estrogen target tissues }\end{array}$ & $\begin{array}{l}\text { Raloxifene } \\
\text { Bazedoxifene } \\
\text { ERB-041 }\end{array}$ & $\begin{array}{l}\text { RCT (Stratton et al. 2008) } \\
\text { None } \\
\text { None }\end{array}$ & Early termination \\
\hline SPRMs & $\begin{array}{l}\text { Progesterone receptor } \\
\text { antagonist/agonist }\end{array}$ & Asoprisnil & RCT (Chwalisz et al. 2005) & $\begin{array}{l}\text { Reduce pain and } \\
\text { dysmenorrhea }\end{array}$ \\
\hline \multicolumn{5}{|l|}{ Non-hormonal agents } \\
\hline \multirow[t]{4}{*}{ Antiangiogenic agents } & Anti-VEGF antibody & Avastatin & None & \\
\hline & $\begin{array}{l}\text { 3-Hydroxy-3-methyl glutaryl } \\
\text { coenzyme A inhibitor }\end{array}$ & Simvastatin & RCT (Almassinokiani et al. 2013) & Reduce pain \\
\hline & Dopamine receptor 2 agonist & Quinagolide & Observational study (Gomez et al. 2011) & Reduce lesion size \\
\hline & $\begin{array}{l}\text { COX-2 inhibitors } \\
\text { Epigallocatechin-3-gallate }\end{array}$ & Celecoxib & $\begin{array}{l}\text { Case-control study (Cobellis et al. 2004) } \\
\text { None }\end{array}$ & Reduce pain \\
\hline \multirow[t]{2}{*}{ Antioxidant agents } & Melatonin & Melatonin & RCT (Schwertner et al. 2013) & $\begin{array}{l}\text { Reduce pain and } \\
\text { dysmenorrhea }\end{array}$ \\
\hline & Pentoxifylline & Pentoxifylline & RCT (Alborzi et al. 2007) & $\begin{array}{l}\text { No effect on pain } \\
\text { or recurrence }\end{array}$ \\
\hline TNF- $\alpha$ blockers & Anti-TNF- $\alpha$ antibody & Infliximab & RCT (Koninckx et al. 2008) & No effect \\
\hline \multirow[t]{2}{*}{ Immunomodulators } & mTOR inhibitor & Rapamycin & None & \\
\hline & $\begin{array}{l}\text { Endogenous eicosanoid, inhibit } \\
\text { MMP-9 }\end{array}$ & LXA4 & None & \\
\hline Apoptotic agent & $\begin{array}{l}\text { Natural polyphenolic compound, } \\
\text { induce p53 mediated apoptosis }\end{array}$ & Curcumin & None & \\
\hline Metformin & $\begin{array}{l}\text { Insulin sensitizer from the family } \\
\text { of the biguanides }\end{array}$ & Metformin & None & \\
\hline \multirow[t]{2}{*}{ MMP inhibitor } & & Doxycycline & None & \\
\hline & & ONO-4817 & None & \\
\hline
\end{tabular}

SERMs, selective estrogen receptor modulators; SPRMs, selective progesterone receptor modulators; MMP, matrix metalloproteinase.

important clues to understanding the molecular etiology of endometriosis and could offer new molecular therapeutic targets to improve the specificity of endometriosis therapy and reduce side effects of current treatments. Based on these findings, several drugs targeting endometriosisspecific inflammation, anti-apoptosis and oxidative stress pathways, as well as alternative hormonal agents, have been developed and examined using in vitro and in vivo endometriosis models. The most recently studied drugs are summarized in Table 1.

\section{Conclusion}

Retrograde menstruation occurs in all women of reproductive age. For reasons that remain unknown, retrograde menstrual tissues develop into endometriotic lesions in $5-10 \%$ of cases. Here, we have discussed how dysregulation of the immune system, apoptosis and oxidative stress are closely associated with endometriosis progression. The dysregulated status of these signaling pathways may predispose women to developing endometriosis, although it remains to be determined what causes such dysregulation in the endometrial tissues to develop into endometriotic lesions. Epigenetic changes caused by nutrition and environmental variables or genetic changes might be potential factors that can initiate endometriosis (Borghese et al. 2017). Moreover, further studies on functional correlation between the dysregulated signals and the severity of endometriosis are clearly needed but, taken together, the dysregulated signals herein we have reviewed may also be connected to disease severity. Future studies must determine how these potential endometriosis initiation factors dysregulate the immune system, apoptosis and oxidative stress pathways, leading to the initiation and progression of endometriosis.

Declaration of interest

The authors declare that there is no conflict of interest that could be perceived as prejudicing the impartiality of this review. 


\section{Funding}

This work was supported by the Eunice Kennedy Shriver National Institute of Child Health and Human Development (NICHD, 5 U24 DK097748-04 Pilot Grant), the Mike Hogg Foundation, the Basic Science Research Program through the National Research Foundation of Korea (NRF) funded by the Ministry of Science, ICT \& Future planning (NRF-2016R1C1B1006976) and the Dong-A University Research Fund (2017)

\section{References}

Abushahin F, Goldman KN, Barbieri E, Milad M, Rademaker A \& Bulun SE 2011 Aromatase inhibition for refractory endometriosisrelated chronic pelvic pain. Fertility and Sterility 96 939-942. (https:// doi.org/10.1016/j.fertnstert.2011.07.1136)

Ahn SH, Edwards AK, Singh SS, Young SL, Lessey BA \& Tayade C 2015 IL-17A contributes to the pathogenesis of endometriosis by triggering proinflammatory cytokines and angiogenic growth factors. Journal of Immunology 195 2591-2600. (https://doi.org/10.4049/ jimmunol.1501138)

Akoum A, Lemay A, Paradis I, Rheault N \& Maheux R 1996 Secretion of interleukin- 6 by human endometriotic cells and regulation by proinflammatory cytokines and sex steroids. Human Reproduction 11 2269-2275. (https://doi.org/10.1093/oxfordjournals.humrep. a019088)

Akoum A, Lawson C, McColl S \& Villeneuve M 2001 Ectopic endometrial cells express high concentrations of interleukin (IL)-8 in vivo regardless of the menstrual cycle phase and respond to oestradiol by up-regulating IL-1-induced IL-8 expression in vitro. Molecular Human Reproduction 7 859-866. (https://doi.org/10.1093/ molehr/7.9.859)

Alborzi S, Ghotbi S, Parsanezhad ME, Dehbashi S, Alborzi S \& Alborzi M 2007 Pentoxifylline therapy after laparoscopic surgery for different stages of endometriosis: a prospective, double-blind, randomized, placebo-controlled study. Journal of Minimally Invasive Gynecology $\mathbf{1 4}$ 54-58. (https://doi.org/10.1016/j.jmig.2006.06.024)

Alizadeh M, Mahjoub S, Esmaelzadeh S, Hajian K, Basirat Z \& Ghasemi M 2015 Evaluation of oxidative stress in endometriosis: a case-control study. Caspian Journal of Internal Medicine 6 25-29.

Almassinokiani F, Mehdizadeh A, Sariri E, Rezaei M Almasi A, Akbari H, Pazooki A, Solaymani-Dodaran M, Asadollah S, Amirkhani J et al. 2013 Effects of simvastatin in prevention of pain recurrences after surgery for endometriosis. Medical Science Monitor 19 534-539. (https://doi.org/10.12659/msm.883967)

Andreoli CG, Genro VK, Souza CA, Michelon T, Bilibio JP, Scheffel C \& Cunha-Filho JS 2011 T helper (Th)1, Th2, and Th17 interleukin pathways in infertile patients with minimal/mild endometriosis. Fertility and Sterility 95 2477-2480. (https://doi.org/10.1016/j. fertnstert.2011.02.019)

Arango Duque G \& Descoteaux A 2014 Macrophage cytokines: involvement in immunity and infectious diseases. Frontiers in Immunology 5491.

Arici A 2002 Local cytokines in endometrial tissue: the role of interleukin-8 in the pathogenesis of endometriosis. Annals of the New York Academy of Sciences 955 101-109. (https://doi. org/10.1111/j.1749-6632.2002.tb02770.x)

Arnold CE, Whyte CS, Gordon P, Barker RN, Rees AJ \& Wilson HM 2014 A critical role for suppressor of cytokine signalling 3 in promoting M1 macrophage activation and function in vitro and in vivo. Immunology 141 96-110. (https://doi.org/10.1111/imm.12173)

Attar E \& Bulun SE 2006 Aromatase inhibitors: the next generation of therapeutics for endometriosis? Fertility and Sterility 85 1307-1318. (https://doi.org/10.1016/j.fertnstert.2005.09.064)

Bacci M, Capobianco A, Monno A, Cottone L, Di Puppo F, Camisa B, Mariani M, Brignole C, Ponzoni M, Ferrari S, et al. 2009
Macrophages are alternatively activated in patients with endometriosis and required for growth and vascularization of lesions in a mouse model of disease. American Journal of Pathology $\mathbf{1 7 5}$ 547-556. (https://doi.org/10.2353/ajpath.2009.081011)

Banu SK, Lee J, Speights VO Jr, Starzinski-Powitz A \& Arosh JA 2009 Selective inhibition of prostaglandin E2 receptors EP2 and EP4 induces apoptosis of human endometriotic cells through suppression of ERK1/2, AKT, NFkappaB, and beta-catenin pathways and activation of intrinsic apoptotic mechanisms. Molecular Endocrinology 23 1291-1305. (https://doi.org/10.1210/me.2009-0017)

Barrier BF 2010 Immunology of endometriosis. Clinical Obstetrics and Gynecology 53 397-402. (https://doi.org/10.1097/ GRF.0b013e3181db7c33)

Bellelis P, Barbeiro DF, Rizzo LV, Baracat EC, Abrao MS \& Podgaec S 2013 Transcriptional changes in the expression of chemokines related to natural killer and T-regulatory cells in patients with deep infiltrative endometriosis. Fertility and Sterility 99 1987-1993. (https://doi. org/10.1016/j.fertnstert.2013.02.038)

Berbic M, Schulke L, Markham R, Tokushige N, Russell P \& Fraser IS 2009 Macrophage expression in endometrium of women with and without endometriosis. Human Reproduction 24 325-332. (https://doi. org/10.1093/humrep/den393)

Berger A 2000 Th1 and Th2 responses: what are they? BMJ 321424. (https://doi.org/10.1136/bmj.321.7258.424)

Bertschi D, McKinnon BD, Evers J, Bersinger NA \& Mueller MD 2013 Enhanced inflammatory activity of endometriotic lesions from the rectovaginal septum. Mediators of Inflammation 2013450950. (https://doi.org/10.1155/2013/450950)

Borghese B, Zondervan KT, Abrao MS, Chapron C \& Vaiman D 2017 Recent insights on the genetics and epigenetics of endometriosis. Clinical Genetics 91 254-264. (https://doi.org/10.1111/cge.12897)

Bulun SE 2009 Endometriosis. New England Journal of Medicine 360 268-279. (https://doi.org/10.1056/NEJMra0804690)

Bulun SE, Monsavais D, Pavone ME, Dyson M, Xue Q, Attar E, Tokunaga H \& Su EJ 2012 Role of estrogen receptor-beta in endometriosis. Seminars in Reproductive Medicine 30 39-45. (https:// doi.org/10.1055/s-0031-1299596)

Carvalho LF, Samadder AN, Agarwal A, Fernandes LF \& Abrao MS 2012 Oxidative stress biomarkers in patients with endometriosis: systematic review. Archives of Gynecology and Obstetrics 286 1033-1040. (https://doi.org/10.1007/s00404-012-2439-7)

Chang KK, Liu LB, Jin LP, Zhang B, Mei J, Li H, Wei CY, Zhou WJ, Zhu XY, Shao J, et al. 2017 IL-27 triggers IL-10 production in Th17 cells via a c-Maf/RORgammat/Blimp-1 signal to promote the progression of endometriosis. Cell Death and Disease 8 e2666. (https://doi.org/10.1038/cddis.2017.95)

Chen P, Zhang Z, Chen Q, Ren F, Li T, Zhang C \& Wang D 2012 Expression of Th1 and Th2 cytokine-associated transcription factors, T-bet and GATA-3, in the eutopic endometrium of women with endometriosis. Acta Histochemica 114 779-784. (https://doi. org/10.1016/j.acthis.2012.01.005)

Chen P, Wang DB \& Liang YM 2016 Evaluation of estrogen in endometriosis patients: regulation of GATA-3 in endometrial cells and effects on Th2 cytokines. Journal of Obstetrics and Gynaecology Research 42 669-677. (https://doi.org/10.1111/jog.12957)

Chwalisz K, Perez MC, Demanno D, Winkel C, Schubert G \& Elger W 2005 Selective progesterone receptor modulator development and use in the treatment of leiomyomata and endometriosis. Endocrine Reviews 26 423-438. (https://doi.org/10.1210/er.20050001)

Cobellis L, Razzi S, De Simone S, Sartini A, Fava A, Danero S, Gioffre W, Mazzini M \& Petraglia F 2004 The treatment with a COX-2 specific inhibitor is effective in the management of pain related to endometriosis. European Journal of Obstetrics, Gynecology, and Reproductive Biology 116 100-102. (https://doi.org/10.1016/j. ejogrb.2004.02.007) 
Collette T, Maheux R, Mailloux J \& Akoum A 2006 Increased expression of matrix metalloproteinase- 9 in the eutopic endometrial tissue of women with endometriosis. Human Reproduction 21 3059-3067. (https://doi.org/10.1093/humrep/del297)

Cordova LA, Loi F, Lin TH, Gibon E, Pajarinen J, Nabeshima A, Lu L, Yao Z \& Goodman SB 2017 CCL2, CCL5 and IGF-1 participate in the immunomodulation of osteogenesis during M1/M2 transition in vitro. Journal of Biomedical Materials Research Part A 105 3069-3076. (https://doi.org/10.1002/jbm.a.36166)

Curtin JF \& Cotter TG 2003 Live and let die: regulatory mechanisms in Fas-mediated apoptosis. Cellular Signalling 15 983-992. (https://doi. org/10.1016/S0898-6568(03)00093-7)

de Barros IBL, Malvezzi H, Gueuvoghlanian-Silva BY, Piccinato CA, Rizzo LV \& Podgaec S 2017 What do we know about regulatory T cells and endometriosis? A systematic review. Journal of Reproductive Immunology 120 48-55. (https://doi.org/10.1016/j.jri.2017.04.003)

Defrere S, Van Langendonckt A, Vaesen S, Jouret M, Gonzalez Ramos R, Gonzalez D, Donnez J 2006 Iron overload enhances epithelial cell proliferation in endometriotic lesions induced in a murine model. Human Reproduction 21 2810-2816. (https://doi.org/10.1093/humrep/ del261)

Defrere S, Gonzalez-Ramos R, Lousse JC, Colette S, Donnez O, Donnez J \& Van Langendonckt A 2011 Insights into iron and nuclear factorkappa B (NF-kappaB) involvement in chronic inflammatory processes in peritoneal endometriosis. Histology and Histopathology $\mathbf{2 6}$ 1083-1092. (https://doi.org/10.14670/HH-26.1083)

Delvoux B, Groothuis P, D'Hooghe T, Kyama C, Dunselman G \& Romano A 2009 Increased production of 17beta-estradiol in endometriosis lesions is the result of impaired metabolism. Journal of Clinical Endocrinology and Metabolism 94 876-883. (https://doi. org/10.1210/jc.2008-2218)

Descamps P \& Lansac J 1998 Gn-RH agonists and ovarian endometriosis. European Journal of Obstetrics and Gynecology and Reproductive Biology 79 143-144. (https://doi.org/10.1016/S0301-2115(98)00068-2)

Diehl S \& Rincon M 2002 The two faces of IL-6 on Th1/Th2 differentiation. Molecular Immunology 39 531-536. (https://doi. org/10.1016/S0161-5890(02)00210-9)

Diehl S, Anguita J, Hoffmeyer A, Zapton T, Ihle JN, Fikrig E \& Rincon M 2000 Inhibition of Th1 differentiation by IL- 6 is mediated by SOCS1. Immunity 13 805-815. (https://doi.org/10.1016/S10747613(00)00078-9)

Dienz O \& Rincon M 2009 The effects of IL-6 on CD4 T cell responses. Clinical Immunology 130 27-33. (https://doi.org/10.1016/j. clim.2008.08.018)

Donnez J, Binda MM, Donnez O \& Dolmans MM 2016 Oxidative stress in the pelvic cavity and its role in the pathogenesis of endometriosis. Fertility and Sterility 106 1011-1017. (https://doi. org/10.1016/j.fertnstert.2016.07.1075)

Dou Q, Williams RS \& Chegini N 1997 Inhibition of transforming growth factor-beta 1 alters the growth, anchor-dependent cell aggregation and integrin mRNA expression in human promonocytes: implications for endometriosis and peritoneal adhesion formation. Molecular Human Reproduction 3 383-391. (https://doi.org/10.1093/molehr/3.5.383)

Dufournet C, Uzan C, Fauvet R, Cortez A, Siffroi JP \& Darai E 2006 Expression of apoptosis-related proteins in peritoneal, ovarian and colorectal endometriosis. Journal of Reproductive Immunology $\mathbf{7 0}$ 151-162. (https://doi.org/10.1016/j.jri.2005.11.003)

Eggert M, Zettl UK \& Neeck G 2010 Autoantibodies in autoimmune diseases. Current Pharmaceutical Design 16 1634-1643. (https://doi. org/10.2174/138161210791164144)

Enokida T \& Nishikawa H 2017 Regulatory T cells, as a target in anticancer immunotherapy. Immunotherapy 9 623-627. (https://doi. org/10.2217/imt-2017-0057)

Eskenazi B \& Warner ML 1997 Epidemiology of endometriosis. Obstetrics and Gynecology Clinics of North America 24 235-258. (https://doi. org/10.1016/S0889-8545(05)70302-8)
Frazer LC, Scurlock AM, Zurenski MA, Riley MM, Mintus M, Pociask DA, Sullivan JE, Andrews CW Jr \& Darville T 2013 IL-23 induces IL-22 and IL-17 production in response to Chlamydia muridarum genital tract infection, but the absence of these cytokines does not influence disease pathogenesis. American Journal of Reproductive Immunology $\mathbf{7 0}$ 472-484. (https://doi.org/10.1111/aji.12171)

Garcia-Velasco JA, Arici A, Zreik T, Naftolin F \& Mor G 1999 Macrophage derived growth factors modulate Fas ligand expression in cultured endometrial stromal cells: a role in endometriosis. Molecular Human Reproduction 5 642-650. (https://doi.org/10.1093/ molehr/5.7.642)

Gebel HM, Braun DP, Tambur A, Frame D, Rana N \& Dmowski WP 1998 Spontaneous apoptosis of endometrial tissue is impaired in women with endometriosis. Fertility and Sterility 69 1042-1047. (https://doi. org/10.1016/S0015-0282(98)00073-9)

Giatromanolaki A, Bates GJ, Koukourakis MI, Sivridis E, Gatter KC, Harris AL \& Banham AH 2008 The presence of tumor-infiltrating FOXP3+ lymphocytes correlates with intratumoral angiogenesis in endometrial cancer. Gynecologic Oncology 110 216-221. (https://doi. org/10.1016/j.ygyno.2008.04.021)

Giudice LC 2010 Endometriosis. New England Journal of Medicine 362 2389-2398. (https://doi.org/10.1056/NEJMcp1000274)

Gomez R, Abad A, Delgado F, Tamarit S, Simon C \& Pellicer A 2011 Effects of hyperprolactinemia treatment with the dopamine agonist quinagolide on endometriotic lesions in patients with endometriosisassociated hyperprolactinemia. Fertility and Sterility 95 882-888.e881. (https://doi.org/10.1016/j.fertnstert.2010.10.024)

Gong D, Shi W, Yi SJ, Chen H, Groffen J \& Heisterkamp N 2012 TGFbeta signaling plays a critical role in promoting alternative macrophage activation. BMC Immunology 13 31. (https://doi. org/10.1186/1471-2172-13-31)

Grund EM, Kagan D, Tran CA, Zeitvogel A, Starzinski-Powitz A, Nataraja S \& Palmer SS 2008 Tumor necrosis factor-alpha regulates inflammatory and mesenchymal responses via mitogen-activated protein kinase kinase, p38, and nuclear factor kappaB in human endometriotic epithelial cells. Molecular Pharmacology 73 1394-1404. (https://doi.org/10.1124/mol.107.042176)

Grunnet LG, Aikin R, Tonnesen MF, Paraskevas S, Blaabjerg L, Storling J, Rosenberg L, Billestrup N, Maysinger D \& Mandrup-Poulsen T 2009 Proinflammatory cytokines activate the intrinsic apoptotic pathway in beta-cells. Diabetes 58 1807-1815. (https://doi.org/10.2337/db080178)

Gupta S, Agarwal A, Krajcir N \& Alvarez JG 2006 Role of oxidative stress in endometriosis. Reproductive BioMedicine Online 13 126-134. (https://doi.org/10.1016/S1472-6483(10)62026-3)

Haanen C \& Vermes I 1996 Apoptosis: programmed cell death in fetal development. European Journal of Obstetrics and Gynecology and Reproductive Biology 64 129-133. (https://doi.org/10.1016/03012115(95)02261-9)

Haber E, Danenberg HD, Koroukhov N, Ron-El R, Golomb G \& Schachter M 2009 Peritoneal macrophage depletion by liposomal bisphosphonate attenuates endometriosis in the rat model. Human Reproduction 24 398-407. (https://doi.org/10.1093/humrep/den375)

Haga HJ, Gjesdal CG, Irgens LM \& Ostensen M 2005 Reproduction and gynaecological manifestations in women with primary Sjogren's syndrome: a case-control study. Scandinavian Journal of Rheumatology 34 45-48. (https://doi.org/10.1080/03009740510017959)

Han SJ, Hawkins SM, Begum K, Jung SY, Kovanci E, Qin J, Lydon JP, DeMayo FJ \& O'Malley BW 2012 A new isoform of steroid receptor coactivator-1 is crucial for pathogenic progression of endometriosis. Nature Medicine 18 1102-1111. (https://doi.org/10.1038/nm.2826)

Han SJ, Jung SY, Wu SP, Hawkins SM, Park MJ, Kyo S, Qin J, Lydon JP, Tsai SY, Tsai MJ, et al. 2015 Estrogen receptor beta modulates apoptosis complexes and the inflammasome to drive the pathogenesis of endometriosis. Cell 163 960-974. (https://doi. org/10.1016/j.cell.2015.10.034) 
Harada T, Kaponis A, Iwabe T, Taniguchi F, Makrydimas G, Sofikitis N, Paschopoulos M, Paraskevaidis E \& Terakawa N 2004 Apoptosis in human endometrium and endometriosis. Human Reproduction Update 10 29-38. (https://doi.org/10.1093/humupd/dmh007)

Harris HA, Bruner-Tran KL, Zhang X, Osteen KG \& Lyttle CR 2005 A selective estrogen receptor-beta agonist causes lesion regression in an experimentally induced model of endometriosis. Human Reproduction 20 936-941. (https://doi.org/10.1093/humrep/deh711)

Harris HR, Simard JF \& Arkema EV 2016 Endometriosis and systemic lupus erythematosus: a population-based case-control study. Lupus 25 1045-1049. (https://doi.org/10.1177/0961203316631635)

Hever A, Roth RB, Hevezi P, Marin ME, Acosta JA, Acosta H, Rojas J, Herrera R, Grigoriadis D, White E, et al. 2007 Human endometriosis is associated with plasma cells and overexpression of B lymphocyte stimulator. PNAS 104 12451-12456. (https://doi.org/10.1073/ pnas.0703451104)

Hong M \& Zhu Q 2004 Macrophages are activated by 17beta-estradiol: possible permission role in endometriosis. Experimental and Toxicologic Pathology 55 385-391. (https://doi.org/10.1078/09402993-00335)

Hornung D, Bentzien F, Wallwiener D, Kiesel L \& Taylor RN 2001 Chemokine bioactivity of RANTES in endometriotic and normal endometrial stromal cells and peritoneal fluid. Molecular Human Reproduction 7 163-168. (https://doi.org/10.1093/molehr/7.2.163)

Hudelist G, Keckstein J, Czerwenka K, Lass H, Walter I, Auer M, Wieser F, Wenzl R, Kubista E \& Singer CF 2005 Estrogen receptor beta and matrix metalloproteinase 1 are coexpressed in uterine endometrium and endometriotic lesions of patients with endometriosis. Fertility and Sterility 84 (Supplement 2) 1249-1256. (https://doi.org/10.1016/j.fertnstert.2005.06.014)

Itoh F, Komohara Y, Takaishi K, Honda R, Tashiro H, Kyo S, Katabuchi H \& Takeya M 2013 Possible involvement of signal transducer and activator of transcription-3 in cell-cell interactions of peritoneal macrophages and endometrial stromal cells in human endometriosis. Fertility and Sterility 99 1705-1713. (https://doi.org/10.1016/j. fertnstert.2013.01.133)

Iwabe T, Harada T, Tsudo T, Nagano Y, Yoshida S, Tanikawa M \& Terakawa N 2000 Tumor necrosis factor-alpha promotes proliferation of endometriotic stromal cells by inducing interleukin- 8 gene and protein expression. Journal of Clinical Endocrinology and Metabolism 85 824-829. (https://doi.org/10.1210/jcem.85.2.6335)

Jeung I, Cheon K \& Kim MR 2016 Decreased cytotoxicity of peripheral and peritoneal natural killer cell in endometriosis. BioMed Research International 2016 2916070. (https://doi. org/10.1155/2016/2916070)

Jorgensen H, Hill AS, Beste MT, Kumar MP, Chiswick E, Fedorcsak P, Isaacson KB, Lauffenburger DA, Griffith LG \& Qvigstad E 2017 Peritoneal fluid cytokines related to endometriosis in patients evaluated for infertility. Fertility and Sterility 107 1191.e1192-1199. e1192. (https://doi.org/10.1016/j.fertnstert.2017.03.013)Josefow icz SZ, Lu LF \& Rudensky AY 2012 Regulatory T cells: mechanisms of differentiation and function. Annual Review of Immunology 30 531-564. (https://doi.org/10.1146/annurev. immunol.25.022106.141623)

Kim BG, Yoo JY, Kim TH, Shin JH, Langenheim JF, Ferguson SD, Fazleabas AT, Young SL, Lessey BA \& Jeong JW 2015 Aberrant activation of signal transducer and activator of transcription-3 (STAT3) signaling in endometriosis. Human Reproduction 30 1069-1078. (https://doi.org/10.1093/humrep/dev050)

Koninckx PR, Craessaerts M, Timmerman D, Cornillie F \& Kennedy S 2008 Anti-TNF-alpha treatment for deep endometriosis-associated pain: a randomized placebo-controlled trial. Human Reproduction 23 2017-2023. (https://doi.org/10.1093/humrep/den177)

Leavy O 2015 Reproductive immunology: evading immunosurveillance in endometriosis. Nature Reviews Immunology 15 729. (https://doi. $\operatorname{org} / 10.1038 /$ nri3942)
Li MQ, Luo XZ, Meng YH, Mei J, Zhu XY, Jin LP \& Li DJ 2012 CXCL8 enhances proliferation and growth and reduces apoptosis in endometrial stromal cells in an autocrine manner via a CXCR1triggered PTEN/AKT signal pathway. Human Reproduction $\mathbf{2 7}$ 2107-2116. (https://doi.org/10.1093/humrep/des132)

Lin YJ, Lai MD, Lei HY \& Wing LY 2006 Neutrophils and macrophages promote angiogenesis in the early stage of endometriosis in a mouse model. Endocrinology 147 1278-1286. (https://doi.org/10.1210/ en.2005-0790)

Mallozzi M, Leone C, Manurita F, Bellati F \& Caserta D 2017 Endocrine disrupting chemicals and endometrial cancer: an overview of recent laboratory evidence and epidemiological studies. International Journal of Environmental Research and Public Health 14. (https://doi. org/10.3390/ijerph14030334)

Malutan AM, Drugan T, Costin N, Ciortea R, Bucuri C, Rada MP \& Mihu D 2015 Pro-inflammatory cytokines for evaluation of inflammatory status in endometriosis. Central European Journal of Immunology 40 96-102. (https://doi.org/10.5114/ceji.2015.50840)

Mandal A \& Viswanathan C 2015 Natural killer cells: in health and disease. Hematology/Oncology and Stem Cell Therapy 8 47-55. (https:// doi.org/10.1016/j.hemonc.2014.11.006)

Martinez FO \& Gordon S 2014 The M1 and M2 paradigm of macrophage activation: time for reassessment. F1000Prime Reports 6 13. (https://doi.org/10.12703/p6-13)

Mathur S, Peress MR, Williamson HO, Youmans CD, Maney SA, Garvin AJ, Rust PF \& Fudenberg HH 1982 Autoimmunity to endometrium and ovary in endometriosis. Clinical and Experimental Immunology 50 259-266.

McKinnon BD, Kocbek V, Nirgianakis K, Bersinger NA \& Mueller MD 2016 Kinase signalling pathways in endometriosis: potential targets for non-hormonal therapeutics. Human Reproduction Update 22. (doi:10.1093/humupd/dmv1060)

McLaren J, Prentice A, Charnock-Jones DS, Sharkey AM \& Smith SK 1997 Immunolocalization of the apoptosis regulating proteins Bcl-2 and Bax in human endometrium and isolated peritoneal fluid macrophages in endometriosis. Human Reproduction 12 146-152. (https://doi.org/10.1093/humrep/12.1.146)

Mei J, Chang KK \& Sun HX 2017 Immunosuppressive macrophages induced by IDO1 promote the growth of endometrial stromal cells in endometriosis. Molecular Medicine Reports 15 2255-2260. (https:// doi.org/10.3892/mmr.2017.6242)

Meresman GF, Vighi S, Buquet RA, Contreras-Ortiz O, Tesone M \& Rumi LS 2000 Apoptosis and expression of Bcl-2 and Bax in eutopic endometrium from women with endometriosis. Fertility and Sterility 74 760-766. (https://doi.org/10.1016/S0015-0282(00)01522-3)

Mier-Cabrera J, Gonzalez-Gallardo S \& Hernandez-Guerrero C 2013 Effect of nitric oxide and TH1/TH2 cytokine supplementation over ectopic endometrial tissue growth in a murine model of endometriosis. Reproductive Sciences 20 1332-1338. (https://doi. org/10.1177/1933719113485297)

Montagna P, Capellino S, Villaggio B, Remorgida V, Ragni N, Cutolo M \& Ferrero S 2008 Peritoneal fluid macrophages in endometriosis: correlation between the expression of estrogen receptors and inflammation. Fertility and Sterility 90 156-164. (https://doi. org/10.1016/j.fertnstert.2006.11.200)

Ngo C, Chereau C, Nicco C, Weill B, Chapron C \& Batteux F 2009 Reactive oxygen species controls endometriosis progression. American Journal of Pathology 175 225-234. (https://doi.org/10.2353/ ajpath.2009.080804)

Nielsen NM, Jorgensen KT, Pedersen BV, Rostgaard K \& Frisch M 2011 The co-occurrence of endometriosis with multiple sclerosis, systemic lupus erythematosus and Sjogren syndrome. Human Reproduction 26 1555-1559. (https://doi.org/10.1093/humrep/der105)

Nothnick WB 2001 Treating endometriosis as an autoimmune disease. Fertility and Sterility 76 223-231. (https://doi.org/10.1016/S00150282(01)01878-7) 
Omwandho CO, Konrad L, Halis G, Oehmke F \& Tinneberg HR 2010 Role of TGF-betas in normal human endometrium and endometriosis. Human Reproduction 25 101-109. (https://doi. org/10.1093/humrep/dep382)

Oosterlynck DJ, Cornillie FJ, Waer M, Vandeputte M \& Koninckx PR 1991 Women with endometriosis show a defect in natural killer activity resulting in a decreased cytotoxicity to autologous endometrium. Fertility and Sterility 56 45-51. (https://doi. org/10.1016/S0015-0282(16)54414-8)

Osuga Y, Koga K, Hirota Y, Hirata T, Yoshino O \& Taketani Y 2011 Lymphocytes in endometriosis. American Journal of Reproductive Immunology 65 1-10. (https://doi. org/10.1111/j.1600-0897.2010.00887.x)

Ouyang W, Kolls JK \& Zheng Y 2008a The biological functions of T helper 17 cell effector cytokines in inflammation. Immunity $\mathbf{2 8}$ 454-467. (https://doi.org/10.1016/j.immuni.2008.03.004)

Ouyang Z, Hirota Y, Osuga Y, Hamasaki K, Hasegawa A, Tajima T, Hirata T, Koga K, Yoshino O, Harada M, et al. 2008b Interleukin-4 stimulates proliferation of endometriotic stromal cells. American Journal of Pathology 173 463-469. (https://doi.org/10.2353/ ajpath.2008.071044)

Palmer MT \& Weaver CT 2010 Autoimmunity: increasing suspects in the CD4+ T cell lineup. Nature Immunology 11 36-40. (https://doi. org/10.1038/ni.1802)

Peter ME, Budd RC, Desbarats J, Hedrick SM, Hueber AO, Newell MK, Owen LB, Pope RM, Tschopp J, Wajant H, et al. 2007 The CD95 receptor: apoptosis revisited. Cell 129 447-450. (https://doi. org/10.1016/j.cell.2007.04.031)

Pirdel L \& Pirdel M 2014 Role of iron overload-induced macrophage apoptosis in the pathogenesis of peritoneal endometriosis. Reproduction 147 R199-R207. (https://doi.org/10.1530/REP-13-0552)

Podgaec S, Abrao MS, Dias JA Jr, Rizzo LV, de Oliveira RM \& Baracat EC 2007 Endometriosis: an inflammatory disease with a Th2 immune response component. Human Reproduction 22 1373-1379. (https:// doi.org/10.1093/humrep/del516)

Rakhila H, Bourcier N, Akoum A \& Pouliot M 2015 Abnormal expression of prostaglandins E2 and F2alpha receptors and transporters in patients with endometriosis. BioMed Research International 2015 808146. (https://doi.org/10.1155/2015/808146)

Ribeiro E, Ladeira C \& Viegas S 2017 EDCs mixtures: a stealthy hazard for human health? Toxics 5 5. (https://doi.org/10.3390/ toxics5010005)

Roberts CA, Dickinson AK \& Taams LS 2015 The interplay between monocytes/macrophages and CD4(+) T cell subsets in rheumatoid arthritis. Frontiers in Immunology 6 571. (https://doi.org/10.3389/ fimmu.2015.00571)

Sakamoto Y, Harada T, Horie S, Iba Y, Taniguchi F, Yoshida S, Iwabe T \& Terakawa N 2003 Tumor necrosis factor-alpha-induced interleukin-8 (IL-8) expression in endometriotic stromal cells, probably through nuclear factor-kappa B activation: gonadotropin-releasing hormone agonist treatment reduced IL-8 expression. Journal of Clinical Endocrinology and Metabolism 88 730-735. (https://doi.org/10.1210/ jc.2002-020666)

Sampson JA 1927 Metastatic or embolic endometriosis, due to the menstrual dissemination of endometrial tissue into the venous circulation. American Journal of Pathology 3 93.43-110.43.

Santanam N, Murphy AA \& Parthasarathy S 2002 Macrophages, oxidation, and endometriosis. Annals of the New York Academy of Sciences $\mathbf{9 5 5}$ 183-198. (https://doi.org/10.1111/j.1749-6632.2002.tb02779.x)

Sbracia M, Valeri C, Antonini G, Biagiotti G, Pacchiarotti A \& Pacchiarotti A 2016 Fas and Fas-ligand in eutopic and ectopic endometrium of women with endometriosis: the possible immune privilege of ectopic endometrium. Reproductive Sciences 23 81-86. (https://doi.org/10.1177/1933719115594019)

Schenk M, Fabri M, Krutzik SR, Lee DJ, Vu DM, Sieling PA, Montoya D, Liu PT \& Modlin RL 2014 Interleukin-1beta triggers the differentiation of macrophages with enhanced capacity to present mycobacterial antigen to T cells. Immunology 141 174-180. (https:// doi.org/10.1111/imm.12167)

Schiemann B, Gommerman JL, Vora K, Cachero TG, Shulga-Morskaya S, Dobles M, Frew E \& Scott ML 2001 An essential role for BAFF in the normal development of B cells through a BCMA-independent pathway. Science 293 2111-2114. (https://doi.org/10.1126/ science.1061964)

Schleich K \& Lavrik IN 2013 Mathematical modeling of apoptosis. Cell Communication and Signaling 11 44. (https://doi.org/10.1186/1478811X-11-44)

Schwertner A, Conceicao Dos Santos CC, Costa GD, Deitos A, de Souza A, de Souza IC, Torres IL, da Cunha Filho JS \& Caumo W 2013 Efficacy of melatonin in the treatment of endometriosis: a phase II, randomized, double-blind, placebo-controlled trial. Pain 154 874-881. (https://doi.org/10.1016/j.pain.2013.02.025)

Selam B, Kayisli UA, Garcia-Velasco JA, Akbas GE \& Arici A 2002 Regulation of fas ligand expression by IL-8 in human endometrium. Journal of Clinical Endocrinology and Metabolism 87 3921-3927. (https://doi.org/10.1210/jcem.87.8.8713)

Selam B, Kayisli UA, Akbas GE, Basar M \& Arici A 2006a Regulation of FAS ligand expression by chemokine ligand 2 in human endometrial cells. Biology of Reproduction 75 203-209. (https://doi.org/10.1095/ biolreprod.105.045716)

Selam B, Kayisli UA, Akbas GE, Basar M \& Arici A 2006b Regulation of FAS ligand expression by chemokine ligand 2 in human endometrial cells. Biology of Reproduction 75 203-209. (https://doi.org/10.1095/ biolreprod.105.045716)

Shao J, Li MQ, Meng YH, Chang KK, Wang Y, Zhang L \& Li DJ 2013 Estrogen promotes the growth of decidual stromal cells in human early pregnancy. Molecular Human Reproduction 19 655-664. (https:// doi.org/10.1093/molehr/gat034)

Shao J, Zhang B, Yu JJ, Wei CY, Zhou WJ, Chang KK, Yang HL, Jin LP, Zhu XY \& Li MQ 2016 Macrophages promote the growth and invasion of endometrial stromal cells by downregulating IL-24 in endometriosis. Reproduction 152 673-682. (https://doi.org/10.1530/REP-16-0278)

Slabe N, Meden-Vrtovec H, Verdenik I, Kosir-Pogacnik R \& Ihan A 2013 Cytotoxic T-cells in peripheral blood in women with endometriosis. Geburtshilfe Frauenheilkd 73 1042-1048. (https://doi. org/10.1055/s-0033-1350702)

Smarr MM, Kannan K \& Buck Louis GM 2016 Endocrine disrupting chemicals and endometriosis. Fertility and Sterility $106959-966$. (https://doi.org/10.1016/j.fertnstert.2016.06.034)

Smith KA, Pearson CB, Hachey AM, Xia DL \& Wachtman LM 2012 Alternative activation of macrophages in rhesus macaques (Macaca mulatta) with endometriosis. Comparative Medicine 62 303-310.

Smyth MJ, Cretney E, Kelly JM, Westwood JA, Street SE, Yagita H, Takeda K, van Dommelen SL, Degli-Esposti MA \& Hayakawa Y 2005 Activation of NK cell cytotoxicity. Molecular Immunology 42 501-510. (https://doi.org/10.1016/j.molimm.2004.07.034)

Sourial S, Tempest N \& Hapangama DK 2014 Theories on the pathogenesis of endometriosis. International Journal of Reproductive Medicine 2014 179515. (https://doi.org/10.1155/2014/179515)

Strasser A, Jost PJ \& Nagata S 2009 The many roles of FAS receptor signaling in the immune system. Immunity 30 180-192. (https://doi. org/10.1016/j.immuni.2009.01.001)

Stratton P, Sinaii N, Segars J, Koziol D, Wesley R, Zimmer C, Winkel C \& Nieman LK 2008 Return of chronic pelvic pain from endometriosis after raloxifene treatment: a randomized controlled trial. Obstetrics and Gynecology 111 88-96. (https://doi.org/10.1097/01. AOG.0000297307.35024.b5)

Takamura M, Koga K, Izumi G, Hirata T, Harada M, Hirota Y, Hiraike O, Fujii T \& Osuga Y 2015 Simultaneous detection and evaluation of four subsets of CD4+ T lymphocyte in lesions and peripheral blood in endometriosis. American Journal of Reproductive Immunology $\mathbf{7 4}$ 480-486. (https://doi.org/10.1111/aji.12426) 
Taniguchi F, Kaponis A, Izawa M, Kiyama T, Deura I, Ito M, Iwabe T, Adonakis G, Terakawa N \& Harada T 2011 Apoptosis and endometriosis. Frontiers in Bioscience 3 648-662. (https://doi. org/10.2741/e277)

Taub DD, Anver M, Oppenheim JJ, Longo DL \& Murphy WJ 1996 T lymphocyte recruitment by interleukin-8 (IL-8). IL-8-induced degranulation of neutrophils releases potent chemoattractants for human T lymphocytes both in vitro and in vivo. Journal of Clinical Investigation 97 1931-1941. (https://doi.org/10.1172/JCI118625)

Taylor HS, Giudice LC, Lessey BA, Abrao MS, Kotarski J, Archer DF, Diamond MP, Surrey E, Johnson NP, Watts NB, et al. 2017 Treatment of endometriosis-associated pain with elagolix, an oral GnRH antagonist. New England Journal of Medicine 377 28-40. (https://doi. org/10.1056/NEJMoa1700089)

Thiruchelvam U, Wingfield M \& O'Farrelly C 2015 Natural killer cells: key players in endometriosis. American Journal of Reproductive Immunology 74 291-301. (https://doi.org/10.1111/aji.12408)

Thornton AM 2005 T regulatory cells. Current Biology 15 R582. (https:// doi.org/10.1016/j.cub.2005.07.048)

Topham NJ \& Hewitt EW 2009 Natural killer cell cytotoxicity: how do they pull the trigger? Immunology 128 7-15. (https://doi. org/10.1111/j.1365-2567.2009.03123.x)

Tsai SJ, Wu MH, Lin CC, Sun HS \& Chen HM 2001 Regulation of steroidogenic acute regulatory protein expression and progesterone production in endometriotic stromal cells. Journal of Clinical Endocrinology and Metabolism 86 5765-5773. (https://doi. org/10.1210/jcem.86.12.8082)

Tsudo T, Harada T, Iwabe T, Tanikawa M, Nagano Y, Ito M, Taniguchi F \& Terakawa N 2000 Altered gene expression and secretion of interleukin-6 in stromal cells derived from endometriotic tissues. Fertility and Sterility 73 205-211. (https://doi.org/10.1016/S0015-0282(99)00496-3)

Urata Y, Osuga Y, Akiyama I, Nagai M, Izumi G, Takamura M, Hasegawa A, Harada M, Hirata T, Hirota Y, et al. 2013 Interleukin-4 and prostaglandin E2 synergistically up-regulate 3betahydroxysteroid dehydrogenase type 2 in endometrioma stromal cells. Journal of Clinical Endocrinology and Metabolism 98 1583-1590. (https://doi.org/10.1210/jc.2012-3475)

Van Langendonckt A, Casanas-Roux F \& Donnez J 2002 Iron overload in the peritoneal cavity of women with pelvic endometriosis. Fertility and Sterility 78 712-718. (https://doi.org/10.1016/S00150282(02)03346-0)

Vanden Eijnden S, Goriely S, De Wit D, Willems F \& Goldman M 2005 IL-23 up-regulates IL-10 and induces IL-17 synthesis by polyclonally activated naive T cells in human. European Journal of Immunology $\mathbf{3 5}$ 469-475. (https://doi.org/10.1002/eji.200425677)

Vetvicka V, Lagana AS, Salmeri FM, Triolo O, Palmara VI, Vitale SG, Sofo V \& Kralickova M 2016 Regulation of apoptotic pathways during endometriosis: from the molecular basis to the future perspectives. Archives of Gynecology and Obstetrics 294 897-904. (https://doi.org/10.1007/s00404-016-4195-6)

Wang XQ, Yu J, Luo XZ, Shi YL, Wang Y, Wang L \& Li DJ 2010 The high level of RANTES in the ectopic milieu recruits macrophages and induces their tolerance in progression of endometriosis. Journal of Molecular Endocrinology 45 291-299. (https://doi.org/10.1677/JME-09-0177)

Wang N, Liang H \& Zen K 2014a Molecular mechanisms that influence the macrophage m1-m2 polarization balance. Frontiers in Immunology 5614 .
Wang Y, Fu Y, Xue S, Ai A, Chen H, Lyu Q \& Kuang Y 2014b The M2 polarization of macrophage induced by fractalkine in the endometriotic milieu enhances invasiveness of endometrial stromal cells. International Journal of Clinical and Experimental Pathology $\mathbf{7}$ 194-203.

Wang Y, Chen H, Wang N, Guo H, Fu Y, Xue S, Ai A, Lyu Q \& Kuang Y 2015 Combined 17beta-estradiol with TCDD promotes M2 polarization of macrophages in the endometriotic milieu with aid of the interaction between endometrial stromal cells and macrophages. PLOS ONE 10 e0125559. (https://doi.org/10.1371/journal. pone.0125559)

Waring P \& Mullbacher A 1999 Cell death induced by the Fas/Fas ligand pathway and its role in pathology. Immunology and Cell Biology 77 312-317. (https://doi.org/10.1046/j.1440-1711.1999.00837.x)

Witz CA, Montoya IA, Dey TD \& Schenken RS 1994 Characterization of lymphocyte subpopulations and T cell activation in endometriosis. American Journal of Reproductive Immunology 32 173-179. (https://doi. org/10.1111/j.1600-0897.1994.tb01110.x)

Wu MH, Lu CW, Chuang PC \& Tsai SJ 2010 Prostaglandin E2: the master of endometriosis? Experimental Biology and Medicine 235 668-677. (https://doi.org/10.1258/ebm.2010.009321)

Wu MH, Chuang PC, Lin YJ \& Tsai SJ 2013 Suppression of annexin A2 by prostaglandin $\mathrm{E}(2)$ impairs phagocytic ability of peritoneal macrophages in women with endometriosis. Human Reproduction $\mathbf{2 8}$ 1045-1053. (https://doi.org/10.1093/humrep/det003)

Xiu-li W, Wen-jun C, Hui-hua D, Su-ping H \& Shi-long F 2009 ERB-041, a selective ER beta agonist, inhibits iNOS production in LPSactivated peritoneal macrophages of endometriosis via suppression of NF-kappaB activation. Molecular Immunology 46 2413-2418. (https://doi.org/10.1016/j.molimm.2009.04.014)

Xue Q, Lin Z, Cheng YH, Huang CC, Marsh E, Yin P, Milad MP, Confino E, Reierstad S, Innes J, et al. 2007 Promoter methylation regulates estrogen receptor 2 in human endometrium and endometriosis. Biology of Reproduction 77 681-687. (https://doi. org/10.1095/biolreprod.107.061804)

Yamauchi N, Harada T, Taniguchi F, Yoshida S, Iwabe T \& Terakawa N 2004 Tumor necrosis factor-alpha induced the release of interleukin- 6 from endometriotic stromal cells by the nuclear factorkappaB and mitogen-activated protein kinase pathways. Fertility and Sterility 82 (Supplement 3) 1023-1028. (https://doi.org/10.1016/j. fertnstert.2004.02.134)

Yeol SG, Won YS, Kim YI, Lee JW, Choi YJ \& Park DC 2015 Decreased Bcl- 6 and increased Blimp-1 in the peritoneal cavity of patients with endometriosis. Clinical and Experimental Obstetrics and Gynecology $\mathbf{4 2}$ 156-160.

Yu YX, Xiu YL, Chen X \& Li YL 2017 Transforming growth factor-beta 1 involved in the pathogenesis of endometriosis through regulating expression of vascular endothelial growth factor under hypoxia. Chinese Medical Journal 130 950-956. (https://doi.org/10.4103/03666999.204112)

Yuan DP, Gu L, Long J, Chen J, Ni J, Qian N \& Shi YL 2014 Shikonin reduces endometriosis by inhibiting RANTES secretion and mononuclear macrophage chemotaxis. Experimental and Therapeutic Medicine 7 685-690. (https://doi.org/10.3892/etm.2013.1458)

Yuan M, Li D, An M, Li Q, Zhang L \& Wang G 2017 Rediscovering peritoneal macrophages in a murine endometriosis model. Human Reproduction 32 94-102.

Received in final form 4 January 2018

Accepted 11 January 2018

Accepted Preprint published online 12 January 2018
C) 2018 Society for Endocrinology Published by Bioscientifica Ltd. Printed in Great Britain 